\title{
Assessment of cyanoprokaryote blooms and of cyanotoxins in Bulgaria in a 15-years period (2000-2015)
}

\author{
Maya P. Stoyneva-Gärtner, ${ }^{1 *}$ Jean-Pierre Descy, ${ }^{2,3}$ Adrien Latli, ${ }^{3}$ Blagoy A. Uzunov, ${ }^{1}$ Vera T. Pavlova, ${ }^{4}$ Zlatka Bratanova, ${ }^{4}$ \\ Pavel Babica, ${ }^{5,6}$ Blahoslav Maršálek, ${ }^{5,6}$ Jussi Meriluoto, ${ }^{7}$ Lisa Spoof ${ }^{7}$
}

\begin{abstract}
${ }^{1}$ Department of Botany, Faculty of Biology, University of Sofia "St Kliment Ohridski”, bld Dragan Zankov 8, BG-1164, Sofia, Bulgaria; ${ }^{2}$ Unité d'Océanographie Chimique, Université de Liège, Sart Tilman, B-4000, Liège, Belgium; ${ }^{3}$ Research Unit in Organismal Biology (URBE), University of Namur, 61 Rue de Bruxelles, 5000 Namur, Belgium; ${ }^{4}$ National Centre of Public Health and Analyses, Str. Academik Ivan Evstratiev Geshov 15, 1431 Sofia, Bulgaria; ${ }^{5}$ Department of Experimental Phycology and Ecotoxicology, Institute of Botany, Czech Academy of Sciences, Lidická 25/27, 60200 Brno, Czech Republic; ${ }^{6}$ RECETOX - Research Centre for Toxic Compounds in the Environment, Faculty of Science, Masaryk University, Kamenice 753/5, 62500 Brno, Czech Republic; ${ }^{7}$ Department of Biochemistry, Faculty of Science and Engineering, Ábo Akademi University, Turku, Finland

*Corresponding author: mstoyneva@uni-sofia.bg
\end{abstract}

\begin{abstract}
The scientific and public awareness of hazardous photosynthetic prokaryotes (cyanobacteria/cyanoprokaryotes) and especially the contamination of drinking-water reservoirs with cyanotoxins is world-wide increasing. Recently much more attention has been paid to the events and results of mass proliferation of these toxic organisms even in South-East European countries in spite of the fact that, as a rule, they are not controlled by national legislation. The present paper presents a summary of results of such studies carried out in summer-autumn periods of the last 15 years (2000-2015) in Bulgarian water bodies differing by location, morphometry and trophic status, incl. drinking-water reservoirs, recreational lakes and sites of nature conservation importance. A multivariate analysis allowed to outline the distribution patterns and environmental drivers of the planktonic cyanoprokaryote assemblages in relation with the available data on the water bodies, highlighting species composition and abundance of the main taxa, including potentially toxic species. Samples analysis by HPLC-DAD and/or LC/MS, ELISA and in vitro cytotoxicity tests allowed detection of microcystins, nodularins and saxitoxins. Toxin concentration ranged between 0.1 and $26.5 \mu \mathrm{g} \mathrm{L}^{-1}$ in water samples and between 10.9 and $1070 \mu \mathrm{g} \mathrm{g} \mathrm{g}^{-1}$ (d.w.) in concentrated (net) samples. Despite the fact that microcystins were not found in all studied water bodies and that the recorded levels were still lower in comparison with some other European countries, the fact that cyanotoxins were detected in 16 water bodies (incl. 3 drinking-water reservoirs) could serve as an alert for the need of recognition of cyanotoxins as a new health risk factor in the country. Therefore, permanent monitoring with identification of toxins in water bodies at risk and activities for limitation and control of toxic blooms are urgently needed, in combination with increase of the attention to the effects of cyanotoxins on both human health and health of aquatic ecosystems in Bulgaria.
\end{abstract}

Key words: Microcystins; nodularins; saxitoxins; reservoirs; lakes; health risk.

Received: 30 September 2016. Accepted: 19 December 2016.

\section{INTRODUCTION}

Current estimates suggest that between 4000 and 5000 phytoplankton species have been described from inland waters (Reynolds, 1996, 2006). Among them are the prokaryotic phototrophs named Cyanoprokaryota (Cyanobacteria, Cyanophyta or Blue-green algae), which are also quantitatively amid the most important organisms on Earth (Whitton and Potts, 2012). Their appearance, traced back to the Early Archaean 3900 Ma ago (Graham et al., 2009), became a crucial step in the evolution of life in water and, subsequently, on land. The later origin and spread of their heterocytous forms, capable of nitrogen fixation, fits well with the timing of Great Oxidation Event about $2400 \mathrm{Ma}$ ago (Schopf, 2012). Since then cyanoprokaryotes are the only nitrogen fixing organisms that also produce oxygen through photosynthesis, with increasing at steady pace number of known non-heterocytous species that possess this ability (Stal, 2012). Considering their additional attribute of buoyancy regulation through gas vacuoles, it is to understand why these peculiar organisms for years remained a fascinating topic (Reynolds, 2006) in biology, with increasing findings of their great potential as providers of ecosystem services. Cyanoprokaryotes are primary colonizers of various (even extreme) habitats, important basis of numerous food chains and have been repeatedly reported for their applications in biotechnology, food industry and pharmacy (Whitton, 2012). However, during the last decades the recognition of the group turned in an almost universal contempt (Reynolds, 2006) due to their potential toxicity, key role in many harmful blooms and general assuming 
hazardous for human and ecosystem health (Carmichael 1994; Codd 1994, 1995; Chorus and Bartram, 1999; Codd et al., 1999, 2005a, 2005b; Maršálek et al., 2000; Huisman et al., 2005; Meriluoto and Codd, 2005; Metcalf and Codd, 2012; Walker, 2015). The situation in Bulgaria is not an exception in this case. Moreover, the country is of intermediate position on the Balkan Peninsula - a great European hotspot of biodiversity (Griffiths et al., 2004). The studies of its water inhabitants have been conducted since more than hundred years and 216 taxa (incl. 170 cyanoprokaryotes and algae), new for the science, have been described (Michev and Stoyneva, 2007). However, the inventory assessment of Bulgarian water bodies (WBs) brought to the recognition of anthropogenically fast eutrophication with nuisance blooms in rapidly increasing numbers of WBs. This situation was considered by the authors as alarming. Since then the number of studies and publications on the cyanotoxins in Bulgarian waters, pioneered by Pavlova et al. (2006), increased and proved their existence in different sites, some of which of high conservational, drinking-water, sport fishing or recreational importance. A part of the results has been published in Bulgarian language, which, in spite of being accepted as one of the official languages of the European Union, remains exotic and not understandable for the majority of scientists. Therefore, the aim of the present paper is to summarize data on cyanotoxins and water blooms in Bulgaria gathered during the last 15 years' period and to assess them on the background of cyanoprokaryote distribution, diversity and abundance in relation to potential toxin producers and driving environmental variables.

\section{METHODS}

\section{Study area}

The study area covers practically the whole territory of Bulgaria $\left(111,000 \mathrm{~km}^{2}\right)$, a part of the eastern Balkan Peninsula with The Danube and Black Sea as north and east borders (Fig. 1). One-third of the country territory is occupied by plains, while the other is covered by hills, plateaus and higher mountains. Its peak Mousala (2925 m) is the highest

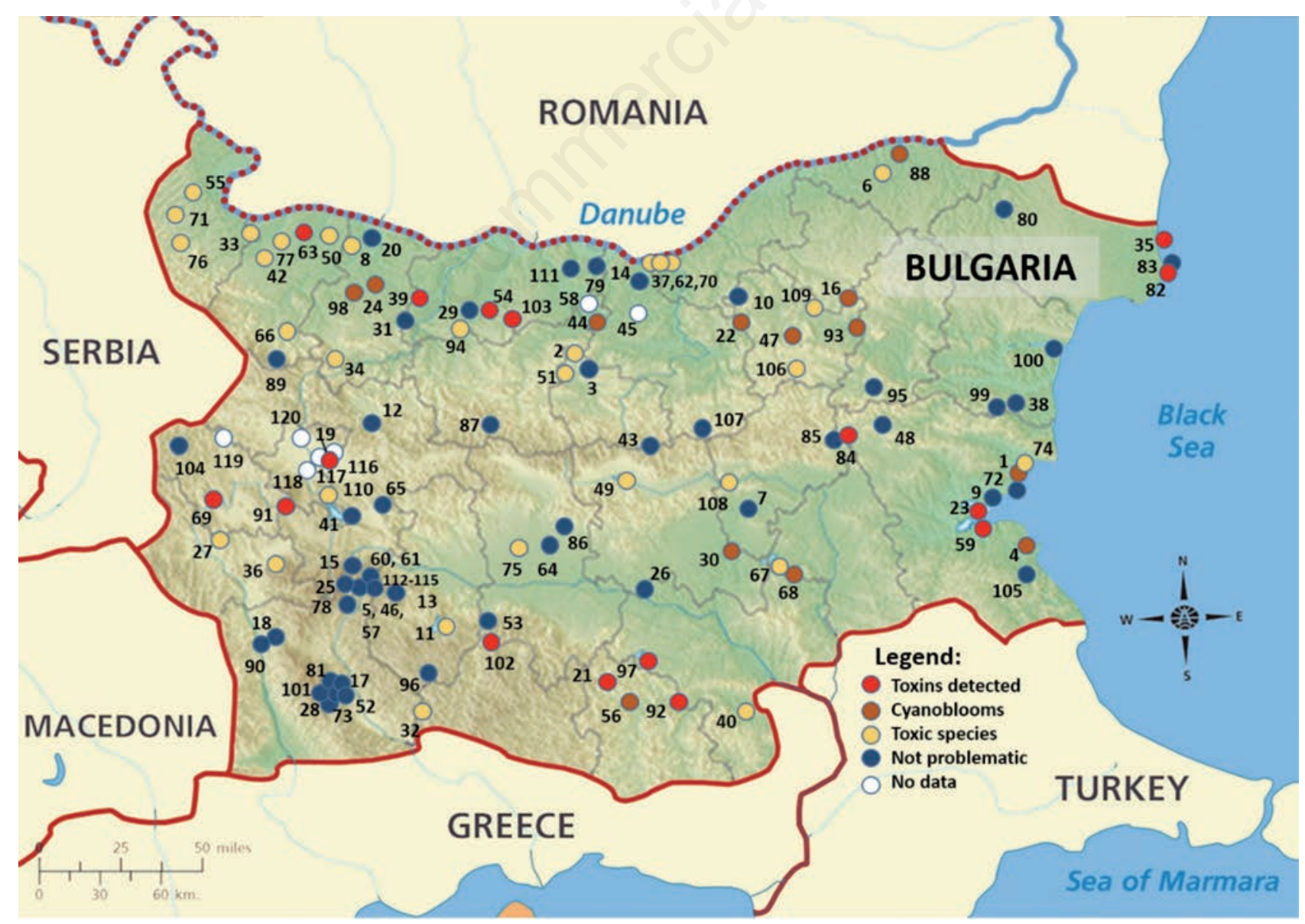

Fig.1. Map of Bulgaria with indication of location of the 120 water bodies studied in 2000-2015. Numeration follows Tab. 1 . 
point of the Balkan Peninsula, while the lowest parts of Bulgaria are at sea level. The climate is temperate continental with a Mediterranean influence in its southern (mainly SW) part with a significant amount of snowfall during winter. Temperature amplitudes vary in different areas (from $-38.3^{\circ} \mathrm{C}$ to $45.2^{\circ} \mathrm{C}$ ) and precipitation range is from $500 \mathrm{~mm}$ in plains to more than $2500 \mathrm{~mm}$ in the mountains, being about $630 \mathrm{~mm}$ per year on average. Due to the interaction of climatic, hydrological, geological and topographical conditions, Bulgaria is one of the countries with highest biodiversity in Europe (Peev et al., 2013). According to the Appendix № XI, map A of Water Framework Directive 2000/60/EC (European Commission, 2000) Bulgaria belongs to the ecoregions № 12 Pontic province and № 7 Eastern Balkans, the borders of which have been updated by Cheshmedjiev et al. (2010b). The results from the first Inventory of Bulgarian wetlands and their biodiversity lead to the conclusion that the country is characterized by great diversity and number of WBs, which cover ca. $1 \%$ of its territory (Michev and Stoyneva, 2007). The term wetlands was consistently used by these authors for all types of WBs, following the definition of Ramsar Convention on wetlands, signed in 1971.

\section{Data collection on planktonic cyanoprokaryotes}

This study compiles and evaluates the currently available data on phytoplankton and relevant environmental data on Bulgarian WBs (mainly reservoirs and lakes) gathered during the period 2000-2015 (Stoyneva, 2003, 2010, 2014, 2015; Beshkova and Botev, 2004; Kalchev et al., 2004; Traykov, 2005; Pavlova et al., 2006, 2013a, 2014, 2015; Beshkova et al., 2008a, 2008b, 2012; Pavlova, 2007; Tsanev and Belkinova, 2008; Teneva et al., 2009, 2010a, 2010b, 2011, 2014; Cheshmedjiev et al., 2010a, 2013; Stoyanov et al., 2012, 2013, 2016; Stoyanov, 2014 Stoyneva et al., 2013, 2015; Belkinova et al., 2014; Dimitrova et al., 2014a, 2014b; Dochin and Stoyneva, 2014, 2015; Dochin, 2015; Georgieva et al., 2015).

The total number of WBs investigated in the above mentioned studies is 115 (Tab. 1, Fig. 1). In addition, five recreational lakes have been checked for cyanotoxins, but data on their phytoplankton composition have not been published (Pavlova, 2007; Pavlova et al., 2013a). They are added in Tab. 1 and Fig. 1 with numbers 116-120. In Tab. 1 we provide the commonly used categories (reservoirs, lakes, swamps, etc.) and the unique number of each WB according to the DataBase of Bulgarian wetlands inventory (IBW - Michev and Stoyneva, 2007), where more details on the origin, location, morphometry, trophic status, history, way of exploitation, conservation, etc. could be found. Since most investigated WBs are reservoirs, in the text bellow, in an operational way, we assign all WBs to two types - reservoirs (R) and other, mainly natural WBs (OWB). According to the geographical location and vertical position all studied WBs could be grouped in the following 8 groups (phyla) of the hierarchical Bulgarian wetland classification (Michev and Stoyneva, 2007): Black Sea coastal surface lowland WBs (CV.I, 0-200 m asl) - 11 (3 R, 8 OWB); Black Sea coastal surface low mountain WBs (CV.IV; $>1000 \mathrm{~m}$ asl $)-1 \mathrm{R}$; Inland surface lowland WBs (LV.I; 0-200 m asl) - 41 (35 R, 6 OWB); Inland surface plain WBs (LV.II; 200-600(700) m asl) - 24 $\mathrm{R}$; Inland surface kettle WBs (LV.III; 500-1000 m asl- 11 (8 R, 3 OWB); Inland surface low mountain WBs (LV.IV; $>1000 \mathrm{~m}$ asl) $-10 \mathrm{R}$; Inland surface middle mountain WBs (LV.V; 1000-1800 m asl-3 (2 R, 1 OWB); Inland surface high mountain and alpine WBs (LV.VI; >1800 m asl -19 ( 2 R, 17 OWB). Among the WBs studied 36 are of conservational importance (Tab. 1): 21 are included in the Red List of Bulgarian wetlands as critically endangered (CR) -9 , endangered (EN) -6 and vulnerable (VU) - 6 (Michev and Stoyneva, 2005, 2007); 36 belong to protected areas with different International and National status (Michev and Stoyneva, 2007); 17 are special subjects of National Action Plan for conservation of wetlands of high significance of Bulgaria for 2013-2022 (Vassilev et al., 2013).

\section{Phytoplankton sampling and laboratory processing}

Phytoplankton sampling procedures and measurements of the main environmental variables (water temperature $\mathrm{t}, \mathrm{pH}$, electric conductivity - cond, Secchi depth - SD, total phosphorus - TP and total nitrogen -TN) were based on International and Bulgarian standards (e.g., CEN EN 15204, 2006; State Order N 4/14.09.2012, 2013; Belkinova and Gecheva, 2013 and references therein). Some studies included more environmental data (chlorophyll $a$, dissolved oxygen, saturation, $\mathrm{NO}_{3}, \mathrm{PO}_{4}$, etc.) with tools and protocols described in detail in the relevant publications, but all of them generally followed the same design. More differences concern the microscopic processing of the samples because the cited standards provide possibilities to choose between inverted microscopy and standard microscopy in combination with different types of counting chambers. In the works of the authors of this paper standard light microscopy was used in combination with Thoma or Burker counting chambers. Always cell was the main counting unit. The biomass estimations were based on the measurement of the dimensions of each cell according to the method of stereometrical approximations (Rott, 1981) instead of the often recommended and broadly applied by other Bulgarian authors usage of average cell sizes. The reasons for choosing this more time-consuming way of work were described in Stoyneva et al. (2015) but for the purpose of the present paper they could be briefly summarised as follows: i) necessity of cell measurements for correct taxa identification; ii) differences in cell size during the cell division process; 3) variations in cell size of the same taxon in different WBs, 
Tab. 1. Bulgarian WBs studied in the period 2000-2015. The names are provided according to the Bulgarian Wetlands Inventory (IBW) through transliteration of their vernacular names; in brackets the synonyms used in the literature.

\begin{tabular}{|c|c|c|c|c|c|c|c|c|}
\hline Number & Name & Type & GL & $\mathbf{A Z}$ & $\mathbf{P A}$ & $\mathbf{R L}$ & NAP & IBWnumber \\
\hline 1 & Aheloy* & $\mathrm{R}$ & CV.IV. & 3 & & & & IBW3032 \\
\hline 2 & Aleksandrovo & $\mathrm{R}$ & LV.I. & 3 & & & & IBW2017 \\
\hline 3 & Aleksandur Stamboliyski* & $\mathrm{R}$ & LV.I. & 3 & & & & IBW2056 \\
\hline 4 & Blato Alepu* & $\mathrm{S}$ & CV.I. & 1 & $\mathrm{x}$ & $\mathrm{CR}$ & & IBW1770 \\
\hline 5 & Musalensko ezero 3 (Alekovo ezero) & $\mathrm{L}$ & LV.VI. & 13 & $\mathrm{x}$ & VU & & IBW0078 \\
\hline 6 & Antimovo* & $\mathrm{R}$ & LV.I. & 3 & & & & IBW 2818 \\
\hline 7 & Asenovets & $\mathrm{R}$ & LVII & 4 & & & & IBW2549 \\
\hline 8 & Asparuhov val* & $\mathrm{R}$ & LV.I. & 2 & & & & IBW 3674 \\
\hline 9 & Atanasovsko ezero* & $\mathrm{L}$ & CV.I. & -1 & $\mathrm{x}$ & VU & $\mathrm{x}$ & IBW1900 \\
\hline 10 & Baniska & $\mathrm{R}$ & LV.I. & 3 & & & & IBW9042 \\
\hline 11 & Batak* & $\mathrm{R}$ & LV.V. & 8 & & & & IBW1316 \\
\hline 12 & Bebresh* & $\mathrm{R}$ & LV.II. & 5 & & & & IBW2397 \\
\hline 13 & Belmeken & $\mathrm{R}$ & LV.VI. & 10 & & & & IBW1187 \\
\hline 14 & Blatse do AEC-Belene & TS & LV.I. & 1 & $\mathrm{x}$ & 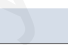 & & IBW4638 \\
\hline 15 & Beli Iskur* & $\mathrm{R}$ & LV.VI. & 10 & $\mathrm{x}$ & & & IBW1180 \\
\hline 16 & Beli Lom & $\mathrm{R}$ & LV.II. & 5 & 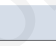 & & & IBW2810 \\
\hline 17 & Bezbozhsko ezero 1 (Ezero Bezbog)* & $\mathrm{L}$ & LV.VI. & 11 & $\mathrm{x}$ & & & IBW0442 \\
\hline 18 & Balastrierni ezera Bistratsite/Bistraka & $\mathrm{L}$ & LV.III. & 5 & & & & IBW4563 \\
\hline 19 & Bistritsa* & $\mathrm{R}$ & LV.III. & 6 & & & & IBW1067 \\
\hline 20 & Blatse do AEC-Kozloduy & $\mathrm{T}$ & LV.I. & 1 & & & & \\
\hline 21 & Borovitsa & $\mathrm{R}$ & LV.IV. & 7 & & & & IBW1580 \\
\hline 22 & Boyka & $\mathrm{R}$ & LV.II & 4 & & & & IBW2573 \\
\hline 23 & Vaya (Burgasko ezero)* & $\mathrm{L}$ & CV.I. & 1 & $\mathrm{x}$ & $\mathrm{CR}$ & $\mathrm{x}$ & IBW0191 \\
\hline 24 & Barzina* & $\mathrm{R}$ & LV.I. & 3 & & & & IBW1276 \\
\hline 25 & Nevenino ezero 1 (Chernoto ezero)* & $\mathrm{L}$ & LV.VI. & 12 & $\mathrm{x}$ & & & IBW0371 \\
\hline 26 & Chirpan* & $\mathrm{R}$ & LV.I. & 3 & & & & IBW1704 \\
\hline 27 & Choklyovo Blato* & $\mathrm{S}$ & LV.V. & 7 & $\mathrm{x}$ & VU & $\mathrm{x}$ & IBW 0003 \\
\hline 28 & Gergiysko ezero $2^{*}$ & $\mathrm{~L}$ & LV.VI. & 12 & $\mathrm{x}$ & & & IBW0480 \\
\hline 29 & Gorni Dabnik* & $\mathrm{R}$ & LV.I. & 3 & & & & IBW 5606 \\
\hline 30 & Daskal Atanasovo & $\mathrm{R}$ & LV.I. & 3 & & & & IBW2219 \\
\hline 31 & Devets (Monchovets) & $\mathrm{R}$ & LV.II & 4 & & & & IBW10869 \\
\hline 32 & Dospat* & $\mathrm{R}$ & LV.V. & 5 & & & & IBW3155 \\
\hline 33 & Drenovets & $\mathrm{R}$ & LV.I. & 3 & & & & IBW1128 \\
\hline 34 & Dabnika & $\mathrm{R}$ & LV.II. & 5 & & & & IBW5393 \\
\hline 35 & Durankulashko ezero (Durankulak)* & $\mathrm{L}$ & CV.I. & 1 & $\mathrm{x}$ & $\mathrm{CR}$ & $\mathrm{x}$ & IBW0216 \\
\hline 36 & Dyakovo* & $\mathrm{R}$ & LV.IV. & 6 & & & & IBW1033 \\
\hline 37 & Blato Dyuleva Bara & $\mathrm{T}$ & LV.I. & 1 & $\mathrm{x}$ & EN & $\mathrm{x}$ & IBW0154 \\
\hline 38 & Eleshnitsa* & $\mathrm{R}$ & LV.I. & 2 & & & & IBW3023 \\
\hline 39 & Enitsa & $\mathrm{R}$ & LV.I. & 3 & & & & IBW1444 \\
\hline 40 & Ivaylovgrad* & $\mathrm{R}$ & LV.I. & 3 & & & & IBW2271 \\
\hline 41 & Iskur* & $\mathrm{R}$ & LV.III. & 7 & & & & IBW1200 \\
\hline 42 & Hr. Smirnenski na reka Lom* & $\mathrm{R}$ & LV.I. & 3 & & & & IBW1135 \\
\hline 43 & Hr. Smirnenski na reka Yantra (Hr. Smirneski/Gabrovo)* & $\mathrm{R}$ & LV.II. & 5 & & & & IBW2080 \\
\hline 44 & Kamenets & $\mathrm{R}$ & LV.I. & 3 & & & & IBW2162 \\
\hline 45 & Karaisen & $\mathrm{R}$ & LV.I. & 3 & & & & IBW5113 \\
\hline 46 & Musalensko ezero 7 (Karakashevo ezero) & $\mathrm{L}$ & LV.VI. & 13 & $\mathrm{x}$ & VU & & IBW0080 \\
\hline 47 & Seyatchi (Kavacite, Popovo)* & $\mathrm{R}$ & LV.II. & 4 & & & & IBW2606 \\
\hline 48 & Kamchiya* & $\mathrm{R}$ & LV.IV. & 5 & & & & IBW2745 \\
\hline 49 & Koprinka* & $\mathrm{R}$ & LV.II. & 5 & & & & IBW2062 \\
\hline 50 & Kovachitsa & $\mathrm{R}$ & LV.I. & 3 & & & & IBW1160 \\
\hline 51 & Krapets* & $\mathrm{R}$ & LV.III. & 5 & & & & IBW2000 \\
\hline 52 & Kremensko ezero $2^{*}$ & $\mathrm{~L}$ & LV.VI. & 12 & $\mathrm{x}$ & & & IBW9088 \\
\hline
\end{tabular}

To be continued on next page 
Tab. 1. Continued from previous page.

\begin{tabular}{|c|c|c|c|c|c|c|c|c|}
\hline Number & Name & Type & GL & $\mathbf{A Z}$ & PA & $\mathbf{R L}$ & NAP & IBWnumber \\
\hline 53 & Krichim & $\mathrm{R}$ & LV.I. & 3 & & & & IBW1366 \\
\hline 54 & Krushovitsa 3 (Krushovitsa) & $\mathrm{R}$ & LV.I. & 1 & & & & IBW1452 \\
\hline 55 & Kula & $\mathrm{R}$ & LV.II. & 4 & & & & IBW1105 \\
\hline 56 & Kardzhali* & $\mathrm{R}$ & LV.II. & 5 & & & & IBW1668 \\
\hline 57 & Musalensko ezero 1 (Ledeno ezero) & $\mathrm{L}$ & LV.VI. & 13 & $\mathrm{x}$ & VU & & IBW0076 \\
\hline 58 & Lazhenska bara (Ladzhenska bara) & $\mathrm{R}$ & LV.I/ & 2 & & & & IBW2166 \\
\hline 59 & Mandra* & $\mathrm{R}$ & CV.I. & 1 & $\mathrm{x}$ & EN & $\mathrm{x}$ & IBW1720 \\
\hline 60 & Marichino ezero 2 (Gorno Marichino ezero) & $\mathrm{L}$ & LV.VI. & 12 & $\mathrm{x}$ & & & IBW0085 \\
\hline 61 & Marichino ezero 3 (Dolno Marichino ezero) & $\mathrm{L}$ & LV.VI. & 12 & $\mathrm{x}$ & & & IBW0086 \\
\hline 62 & Murtvo blato & TS & LV.I. & 1 & $\mathrm{x}$ & $\mathrm{EN}$ & $\mathrm{x}$ & IBW0158 \\
\hline 63 & Ezero Momin brod* & $\mathrm{L}$ & LV.I. & 1 & & & & IBW8307 \\
\hline 64 & Novo Zhelezare & $\mathrm{R}$ & LV.II. & 4 & & & & IBW1475 \\
\hline 65 & Ognyanovo* & $\mathrm{R}$ & LV.III. & 6 & & & & IBW2340 \\
\hline 66 & Ogosta* & $\mathrm{R}$ & LV.I. & 3 & & & & IBW 1137 \\
\hline 67 & Ovcharitsa & $\mathrm{R}$ & LV.I. & 3 & $\mathrm{x}$ & ) & $\mathrm{x}$ & IBW2317 \\
\hline 68 & Ovchi kladenets & $\mathrm{R}$ & LV.I. & 3 & 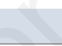 & & & IBW2367 \\
\hline 69 & Pchelina* & $\mathrm{R}$ & LV.III. & 6 & (3) & & & IBW1039 \\
\hline 70 & Blato Peschina (Pischina) & $\mathrm{T}$ & LV.I. & 1 & $\mathrm{x}$ & EN & $\mathrm{x}$ & IBW0156 \\
\hline 71 & Poletkovtsi 2 (Poletkovtsi)* & $\mathrm{R}$ & LV.II. & 4 & & & & IBW1103 \\
\hline 72 & Pomoriysko ezero* & $\mathrm{L}$ & CV.I. & -1 & $\mathrm{x}$ & VU & $\mathrm{x}$ & IBW 0189 \\
\hline 73 & Popovo ezero 2 (Popovo ezero)* & $\mathrm{L}$ & LV.VI. & 11 & $\mathrm{x}$ & & & IBW0447 \\
\hline 74 & Poroy* & $\mathrm{R}$ & CV.I. & 2 & & & & IBW3038 \\
\hline 75 & Pyasuchnik 1 (Pyasuchnik)* & $\mathrm{R}$ & LV.II. & 4 & & & $\mathrm{x}$ & IBW5834 \\
\hline 76 & Rabisha* & $\mathrm{R}$ & LV.II. & 4 & & & & IBW1102 \\
\hline 77 & Rasovo 2 (Rasovo) & $\mathrm{R}$ & LV.I. & 3 & & & & IBW1158 \\
\hline 78 & Redzhepsko ezero 2 (Redzhepsko ezero) & $\mathrm{R}$ & LV.VI. & 12 & $\mathrm{x}$ & & & IBW0342 \\
\hline 79 & Dragash Voyvoda & $\mathrm{R}$ & LV.I. & 1 & $\mathrm{x}$ & & & IBW3935 \\
\hline 80 & Onogour (Efreytor Bakalovo) & $\mathrm{R}$ & LV.I. & 3 & $\mathrm{x}$ & & & IBW5667 \\
\hline 81 & Bunderishko ezero 9 (Ribno ezero)* & $\mathrm{L}$ & LV.VI. & 11 & $\mathrm{x}$ & & & IBW0400 \\
\hline 82 & Shablensko ezero (Shabla)* & $\mathrm{L}$ & CV.I. & 1 & $\mathrm{x}$ & $\mathrm{CR}$ & $\mathrm{x}$ & IBW0219 \\
\hline 83 & Shablenska tuzla & $\mathrm{L}$ & CV.I. & -1 & & EN & & IBW0218 \\
\hline 84 & Kayabash 2 (Golyamo Skalensko ezero) & $\mathrm{R}$ & LV.IV. & 5 & & & & IBW2659 \\
\hline 85 & Kayabash 1 (Malko Skalensko ezero) & $\mathrm{R}$ & LV.IV. & 5 & & & & IBW2658 \\
\hline 86 & Hisar 12 (Sinyata reka)* & $\mathrm{R}$ & LV.II. & 5 & & & & IBW1893 \\
\hline 87 & Sopot* & $\mathrm{R}$ & LV.II. & 5 & & & & IBW1437 \\
\hline 88 & Blato Srebarna* & $\mathrm{L}$ & LV.I. & 1 & $\mathrm{x}$ & EN & $\mathrm{x}$ & IBW0208 \\
\hline 89 & Srechenska bara* & $\mathrm{R}$ & LV.IV. & 5 & & & & IBW3668 \\
\hline 90 & Stoychovtsi (Stoykovtsi) & $\mathrm{R}$ & LV.IV. & 8 & & & & IBW3237 \\
\hline 91 & Studena* & $\mathrm{R}$ & LV.IV. & 7 & & & & IBW 1060 \\
\hline 92 & Studen kladenets* & $\mathrm{R}$ & LV.II. & 4 & & & & IBW1763 \\
\hline 93 & Suedinenie* & $\mathrm{R}$ & LV.I. & 3 & & & & IBW2642 \\
\hline 94 & Telish* & $\mathrm{R}$ & LV.I. & 3 & & & & IBW1413 \\
\hline 95 & Ticha* & $\mathrm{R}$ & LV.I. & 3 & & & & IBW2700 \\
\hline 96 & Toshkov chark & $\mathrm{R}$ & LV.V. & 9 & $\mathrm{x}$ & & & IBW1315 \\
\hline 97 & Trakiets & $\mathrm{R}$ & LV.II. & 4 & & & & IBW1677 \\
\hline 98 & Tri kladentsi* & $\mathrm{R}$ & LV.I. & 3 & & & & IBW1275 \\
\hline 99 & Tsonevo* & $\mathrm{R}$ & LV.I. & 2 & & & & IBW3022 \\
\hline 100 & Varnensko ezero* & $\mathrm{L}$ & CV.I. & 1 & $\mathrm{x}$ & $\mathrm{CR}$ & & IBW0203 \\
\hline 101 & Vlahinsko ezero $1^{*}$ & $\mathrm{~L}$ & LV.VI. & 12 & $\mathrm{x}$ & & & IBW0475 \\
\hline 102 & Vucha & $\mathrm{R}$ & LV.I. & 3 & & & & IBW 3143 \\
\hline 103 & Valchovets & $\mathrm{R}$ & LV.I. & 2 & & & & IBW2129 \\
\hline 104 & Yarlovets (Yarlovtsi) & $\mathrm{R}$ & LV.IV. & 7 & & & & IBW 1038 \\
\hline 105 & Yasna polyana* & $\mathrm{R}$ & CV.I. & 2 & & & & IBW2887 \\
\hline
\end{tabular}


Tab. 1. Continued from previous page.

\begin{tabular}{|c|c|c|c|c|c|c|c|c|}
\hline Number & Name & Type & GL & $\mathbf{A Z}$ & $\mathbf{P A}$ & $\mathbf{R L}$ & NAP & IBWnumber \\
\hline 106 & Yastrebino* & $\mathrm{R}$ & LV.II. & 5 & & & & IBW2602 \\
\hline 107 & Shilkovtsi (Yovkovtsi)* & $\mathrm{R}$ & LV.II. & 5 & & & & IBW2105 \\
\hline 108 & Zhrebchevo* & $\mathrm{R}$ & LV.II. & 4 & & & & IBW2545 \\
\hline 109 & Lomtsi & $\mathrm{R}$ & LV.II. & 4 & & & & IBW2772 \\
\hline 110 & Pancharevo & $\mathrm{R}$ & LV.III. & 6 & & & & IBW1088 \\
\hline 111 & Zhernov & $\mathrm{R}$ & LV.I. & 2 & & & & IBW4639 \\
\hline 112 & Ezero Bliznaka & $\mathrm{L}$ & LV.VI. & 11 & $\mathrm{x}$ & $\mathrm{CR}$ & $\mathrm{x}$ & IBW0350 \\
\hline 113 & Ezero Bubreka & $\mathrm{L}$ & LV.VI. & 11 & $\mathrm{x}$ & CR & $\mathrm{x}$ & IBW0349 \\
\hline 114 & Ezero Okoto & $\mathrm{L}$ & LV.VI. & 12 & $\mathrm{x}$ & $\mathrm{CR}$ & $\mathrm{x}$ & IBW0348 \\
\hline 115 & Ezero Sulzata & $\mathrm{L}$ & LV.VI. & 12 & $\mathrm{x}$ & CR & $\mathrm{x}$ & IBW0347 \\
\hline 116 & Balastrierni ezera Dolni Bogrov & $\mathrm{L}$ & LV.III. & 6 & & & & IBW0708 \\
\hline 117 & Botunets & $\mathrm{R}$ & LV.III. & 6 & & & & IBW1792 \\
\hline 118 & Ezero $1 \mathrm{v}$ kvartal Druzhba & $\mathrm{L}$ & LV.III. & 6 & & & & IBW5284 \\
\hline 119 & Krasava & $\mathrm{R}$ & LV.IV. & 7 & & & & IBW1049 \\
\hline 120 & Rudnichno ezero Kutina 1 & $\mathrm{~L}$ & LV.III. & 6 & 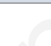 & 8 & & IBW0705 \\
\hline
\end{tabular}

*Denote WB included in the dataset for the Principal component analysis (PCA) and Redundancy analysis (RDA) for this paper. R, reservoir; L, lake; S, swamp; T, temporary swamp. For each WB, the main group of geographic location and vertical position (GL) is shown (CV.I - LV.VI) and altitude zone (AZ) in 14 elevation classes (-1 -13); for details on GL and AZ see the text. The conservation value of the WB is provided as protected area (PA), National Action Plan for conservation of wetlands of high significance of Bulgaria for 2013-2022 (NAP) and Red List of Bulgarian Wetlands (RL); CR, critically endangered; EN, endangered; VU, vulnerable. IBW number is the number of WB in the Bulgarian Wetlands Inventory (Michev and Stoyneva, 2007), where more details on them could be found.

or even in the same water body due to different temperature, nutrient content or grazing pressure (Stoyneva et al., 2007). We believe that the results obtained in this way reflect the real biomass for a given time and site, especially when the samples are analysed by the same person.

\section{Multivariate analyses}

Considering the reasons stated above, after analyzing of all available, but quite heterogenous data on the 20002015 phytoplankton in Bulgarian WBs (references provided in the "Data Collection" paragraph above), we chose to build a homogenous data set (Stoyneva, 2014, 2015; this study) by including only the WBs (sites) with at last 5 samples processed per site, for which the environmental data listed above were available. WBs in which cyanotoxins have been investigated by the authors of this paper, have been included in the dataset. In addition, WBs were chosen to represent all 8 general groups (from CV.I to LV.VI) proposed in the Bulgarian wetlands classification and the CR, EN and VU conservational threat categories (Michev and Stoyneva 2005, 2007) as well. In this way, the final dataset comprised $61 \mathrm{WBs}$ (marked with asterisk* in Tab. 1) and average values of biomass of 93 species, varieties and forms grouped in 24 genera, environmental data, total cyanoprokaryote biomass (TBC), total phytoplankton biomass (TBS). The dataset also includes average data biomass of other phytoplankton dominant groups, as well as data on WBs morphometry (area and depth), geographic location in the 8 groups of Michev and Stoyneva (2007), exact altitude asl (m) or as 14 elevation classes proposed in the IBW DataBase of Michev and Stoyneva (2007): -1 - below 0; 1-0-50; 2 - 50-100; 3 - 100-200; 4 - 200-300; 5 - 300-500; 6 - 500-700; 7 - 700-1000; 8 - 1000-1100; 9 - 1100-1600; $10-1600$ $2000 ; 11-2000-2300 ; 12-2300-2700 ; 13->2700 \mathrm{~m}$ asl.

Multivariate analyses were run using principal components analyis (PCA) and redundancy analysis (RDA), using the R-software (R 3.1.2 version, R Development Core Team, 2010) and the "ADE4" package (Thioulouse et al., 1997). The aims were i) to identify the main environmental gradients among the samples of lakes/reservoirs and ii) to investigate the response of the cyanoprokaryote assemblages (at the genus level) to these gradients. All variables were normalised; the cyanobacterial abundances were transformed using the Hellinger transformation (Legendre and Gallagher, 2001).

\section{Taxonomic sources, terminology and biodiversity assessment}

Taxonomic sources include mainly the standardly used volumes of Middle European freshwater flora with some published updates (Komárek 2013; Komárek and Anagnostidis 1999, 2005; Komárek et al. 2011, etc.) and AlgaeBase (Guiry and Guiry 2016). The Latin names follow the above mentioned botanical sources and the International Code of the Nomenclature for algae, fungi and plants (McNeil et al., 2012). Therefore, the term cyanoprokaryotes is used in 
the paper instead of cyanobacteria. For each species and genus, the frequency quotient (FQ) of occurrence in all studied sites was estimated based on its presence / absence in each site. The frequency quotients were grouped in classes with a step of $10 \%$ (I class $-0-10 \%$, II class - 10 $20 \%$, etc.). The evaluation of cyanoprokaryote diversity was done as comparisons with the recently estimated data on the total algal biodiversity in Bulgaria (Stoyneva, 2014) and the total diversity of Cyanoprokaryota in the country (Stoyneva et al., 2016).

\section{Collection and assessment of cyanotoxin data, algal blooms and potential toxin producers}

The assessment of cyanotoxins registered in the country in relation to their potential producers is based on the works of Pavlova (2007), Pavlova et al. (2006, 2007, 2013a, 2014, 2015), Teneva et al. (2009, 2010a, 2010b, 2011, 2014), Stoyanov et al. (2012) and Georgieva et al. (2015) - Tabs. 2 and 3. For this study the biomass of the species published earlier by Pavlova et al. $(2006,2014)$ with their cell numbers per liter (or milliliter) was estimated (Tabs. 2 and 3). Results on toxin findings were superimposed on the data on phytoplankton blooms according to the references in Tabs. 2 and 3. The cyanotoxin concentrations were evaluated according to the WHO standards $(1998,2003)$ since their maximum acceptable levels are not indicated in Bulgarian national legislation (Pavlova et al., 2013b).

\section{RESULTS}

\section{Diversity and abundance of cyanoprokaryotes}

A total of 210 taxa (207 species, 1 variety and 2 forms) from 69 genera of Cyanoprokaryota were recorded in the 2000-2015 period. The distribution of species in the three orders Chroococcales, Oscillatoriales and Nostocales clearly shows the Chroococcales (85) as the richest order and the better representation of non-heterocytous filamentous forms (69) in comparison with hetereocytous, filamentous taxa (56). At the genus level, heterocytous taxa (17) were also less numerous than non-heterocytous filamentous (21) and than coccal taxa (31). The most speciesrich genera were Dolichospermum (11), Microcystis (11), Anabaena (9), Aphanocapsa (9), Oscillatoria (9), Chroococcus (8), Phormidium (8), Pseudanabaena (8), Romeria (8), Anabaenopsis (6) and Aphanizomenon (6).

Most of the species were rare ( 96 were found only in one site) and FQ ranged from 1 to $34 \%$. Among the 19 broadly distributed algae (in $\geq 11$ sites), 14 have been identified at species level (Fig. 2), with Aphanizomenon flosaquae Ralfs ex Bornet \& Flahault being the most widespread taxon.

Most of the 69 genera were rare (18 were found in one site), with $\mathrm{FQ}$ range from 1 to $43 \%$. The 22 genera with the widest distribution (in $\geq 12$ sites) are shown on Fig. 3: Aphanizomenon is outstanding as the most widespread genus in

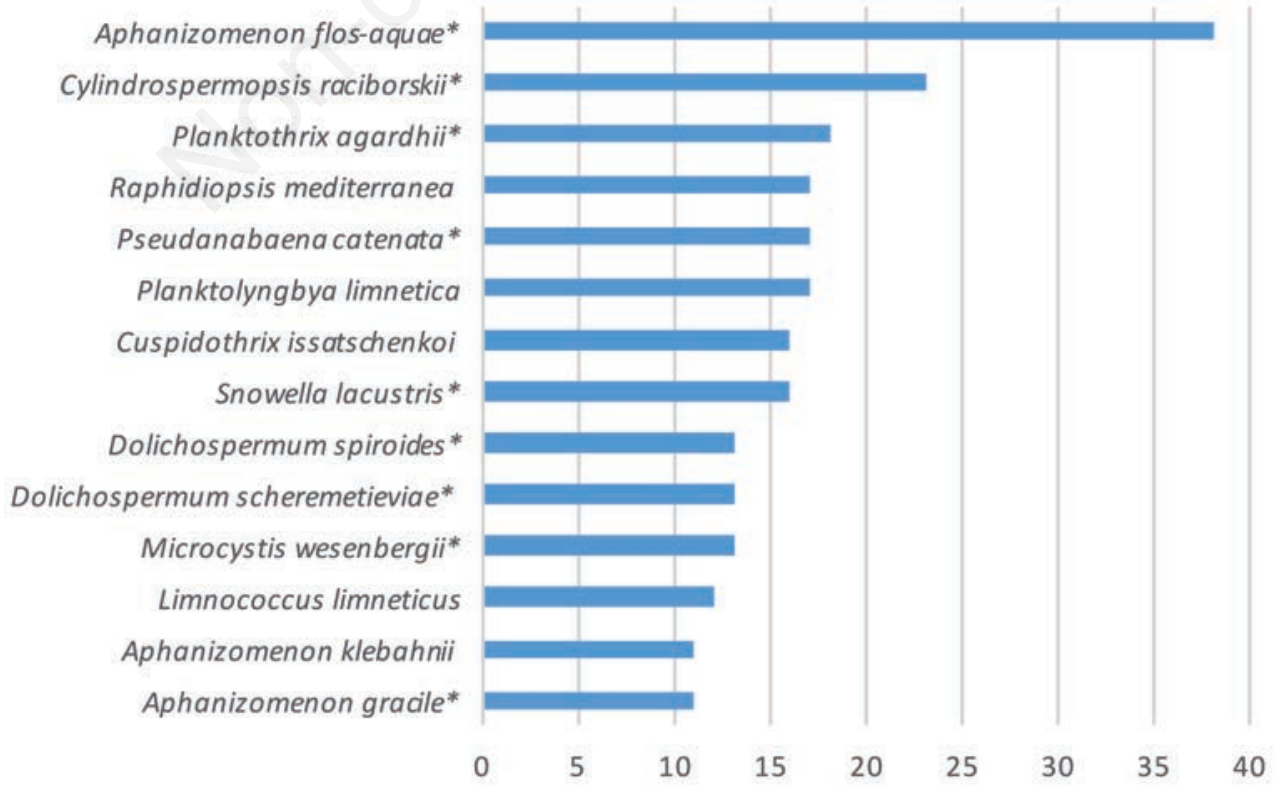

Fig. 2. Distribution of the most widespread cyanoprokaryotes in the phytoplankton of Bulgarian water bodies in the period $2000-2015$. $0-40$, number of water bodies in which species were found; *species found in the samples containing cyanotoxins. 


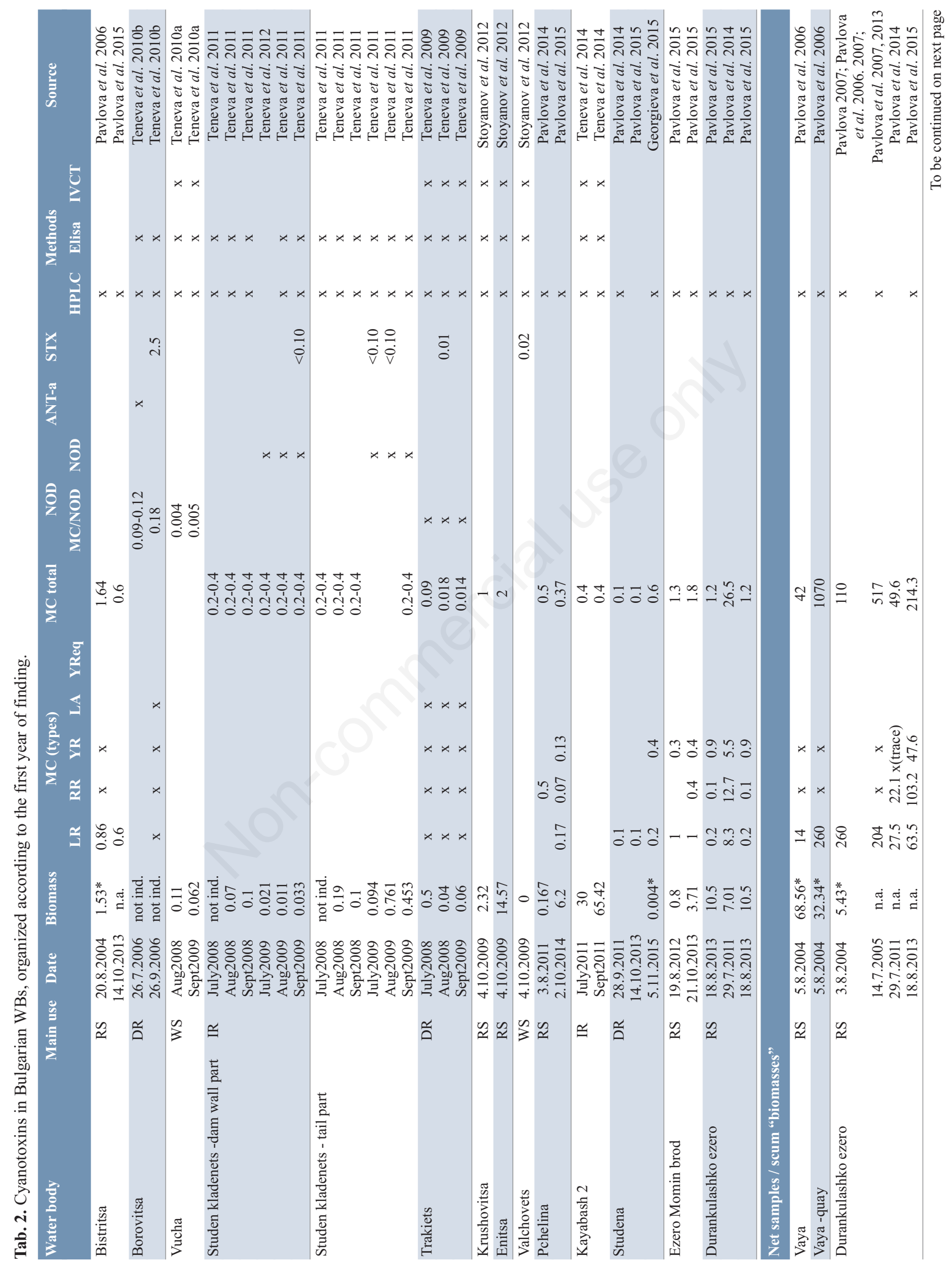




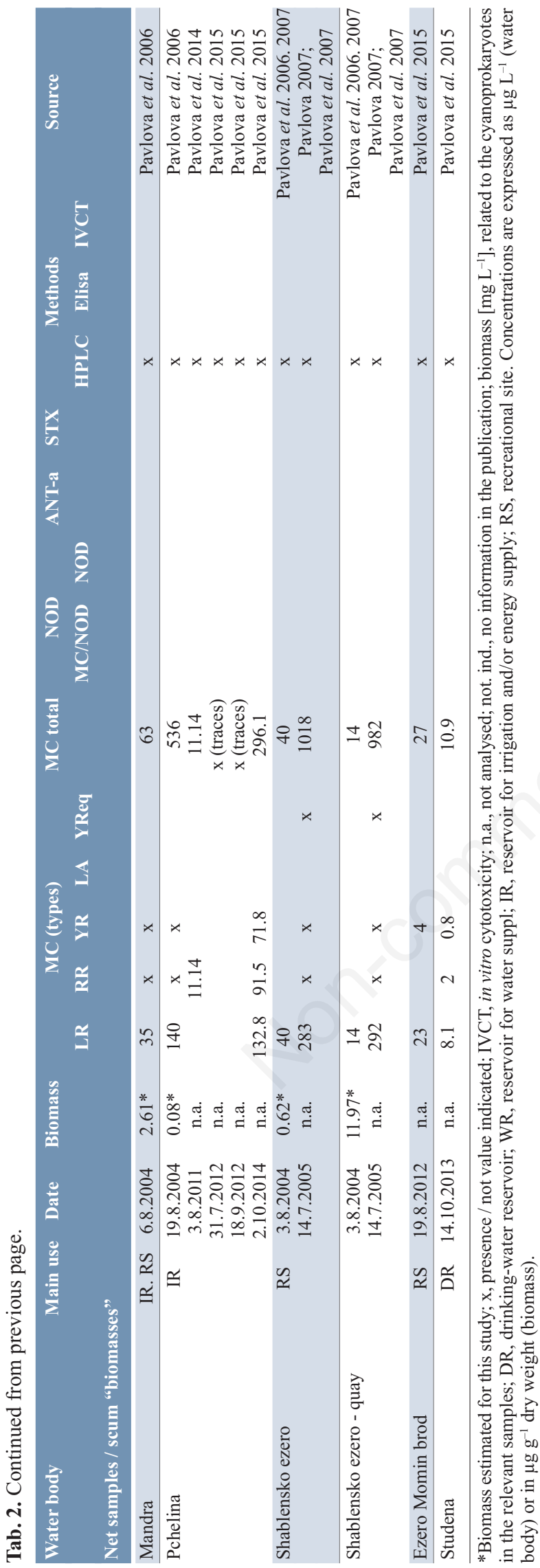

the country during the analyzed period. In this study, we classified as picoplankton single spherical cells of dimensions 0.5-1.5 $\mu \mathrm{m}$, commonly referred as Pcy (picocyanobacteria) in contrast to the second morphological group of colonial picoplankters - CPcy (colonial picocyanobacteria) - Stockner et al. (2002), Callieri et al. (2012).

The number of species and genera per site ranged between (0) 1 and 85, and 1 to 35 , respectively (Fig. 4), the highest number detected in the shallow lakes Blato Srebarna (site 88: 85/35) and Vaya (site 23: 63/30). The comparison of distribution of species and genera per site, expressed on Fig. 4, shows that in most of the WBs each genus is represented by a single species, which makes the discussion of the distribution on generic level and further PCA analysis quite reasonable.

The contribution of the cyanoprokaryotes to the total phytoplankton biomass in different WBs and in different sampling periods ranged from 0 to $100 \%$, with values exceeding $65-75 \mathrm{mg} \mathrm{L}^{-1}$ in summer periods (e.g., in the coastal lake Vaya - Stoyneva, 2003; Pavlova et al., 2006, 2007; Dimitrova et al., 2014a) and reaching $95.9 \mathrm{mg} \mathrm{L}^{-1}$ in average for the period 2010-2014 (this study). The assessment of the average cyanoprokaryote biomass in 61 WBs from the dataset shows that in four sites (the lakes Vaya and Blato Srebarna, and the reservoirs Mandra and Tri kladentsi), its values were over WHO's (2003) threshold for medium health risk category $\left(10 \mathrm{mg} \mathrm{L}^{-1}\right)$ in recreational waters and in five other (the lakes Durankulashko ezero and Ezero Momin brod, and the reservoirs Asparuhov val, Chirpan and Pchelina) from the rest $57 \mathrm{WBs,}$ they were over the low health risk category threshold (2 $\mathrm{mg} \mathrm{L}^{-1}$ ), as they were re-estimated from cell numbers in biomass values by Mishke et al. (2011).

The single investigation of steady-states, as Sommer and Padisák (1993) have defined them, outlined their presence in the period analyzed for this paper only in the lake Vaya: 3 weeks dominance (89\%) of Microcystis wesenbergii (Komárek) Komárek in Kondratieva, Aphanizomenon flos-aquae and Dolichospermum spiroides (Klebahn) Wacklin et al. in August-September 2001 and 4 weeks dominance (98\%) of M. wesenbergii and Aphanizomenon gracile (Lemmermann) Lemmermann in AugustSeptember 2002 (Stoyneva, 2003). The lake Vaya is the only WB for which the total carbon content was estimated (Dimitrova et al., 2014a). Its mean value of $9.7 \mathrm{mg} \mathrm{L}^{-1}$ (2004-2006) together with the average biomass of $46 \mathrm{mg}$ $\mathrm{L}^{-1}$ for the same period confirmed the hypertrophic status of the lake. Cyanoprokaryotes dominated constantly in the total carbon content, reaching absolute maxima of 25.1 and $26.9 \mathrm{mg} \mathrm{L}^{-1}$ in August 2005 and 2006. Dominance of this group with water blooms (up to $200 \mathrm{mg} \mathrm{L}^{-1}$ ) was detected also in more recent studies of this shallowest coastal lake and, in parallel, cyanoprokaryote blooms were documented for 19 more Bulgarian WBs: Alepu, Durankulashko ezero, 
Tab. 3. Water samples with negative results for cyanotoxins in Bulgarian WBs (2000-2015).

\begin{tabular}{|c|c|c|c|c|c|}
\hline \multirow{2}{*}{$\begin{array}{l}\text { Water body -water samples checked for toxins with } \\
\text { negative results/organized by years of the investigations }\end{array}$} & \multirow[t]{2}{*}{ Date } & \multicolumn{3}{|c|}{ Methods } & \multirow[t]{2}{*}{ Source } \\
\hline & & HPLC & Elisa & In vitro $\mathrm{CT}$ & \\
\hline Botunets & 20.8 .2004 & $\mathrm{x}$ & & & Pavlova et al. 2006 \\
\hline Ezeretsko ezero & $\begin{array}{l}3.8 .2004 \\
2005\end{array}$ & $\begin{array}{l}\mathrm{x} \\
\mathrm{x}\end{array}$ & & & $\begin{array}{c}\text { Pavlova et al. } 2006 \\
\text { Pavlova 2007; Pavlova et al. 2013a }\end{array}$ \\
\hline Choklyovo blato & $\begin{array}{l}19.8 .2004 \\
2005\end{array}$ & $\begin{array}{l}\mathrm{x} \\
\mathrm{x}\end{array}$ & & & $\begin{array}{c}\text { Pavlova et al. } 2006 \\
\text { Pavlova 2007; Pavlova et al. 2013a }\end{array}$ \\
\hline Balastrierni ezera Dolni Bogrov & 20.8 .2004 & $\mathrm{x}$ & & & Pavlova et al. 2006 \\
\hline Ezero $1 \mathrm{v}$ kvartal Druzhba & 27.8 .2004 & $\mathrm{x}$ & & & Pavlova et al. 2006 \\
\hline Iskur & $\begin{array}{c}18.8 .2004 \\
2005\end{array}$ & $\begin{array}{l}\mathrm{x} \\
\mathrm{x}\end{array}$ & & & $\begin{array}{c}\text { Pavlova et al. } 2006 \\
\text { Pavlova 2007; Pavlova et al. 2013a }\end{array}$ \\
\hline Rudnichno ezero Kutina 1 & 20.8 .2004 & $\mathrm{x}$ & & & Pavlova et al. 2006 \\
\hline Studena & $\begin{array}{c}19.8 .2004 \\
2005 \\
31.7 .2012 \\
3.8 .2011 \\
18.9 .2012 \\
12.8 .2013 \\
2.10 .2014 \\
4.8 .2015\end{array}$ & $\begin{array}{l}\mathrm{x} \\
\mathrm{x} \\
\mathrm{x} \\
\mathrm{x} \\
\mathrm{x} \\
\mathrm{x} \\
\mathrm{x} \\
\mathrm{x}\end{array}$ & & & $\begin{array}{c}\text { Pavlova et al. } 2006 \\
\text { Pavlova 2007; Pavlova et al. 2013a } \\
\text { Pavlova et al. } 2015 \\
\text { Pavlova et al. } 2014 \\
\text { Pavlova et al. } 2015 \\
\text { this study } \\
\text { Pavlova et al. } 2015 \\
\text { Georgieva et al. } 2015\end{array}$ \\
\hline Yasna polyana & $\begin{array}{l}6.8 .2004 \\
2005\end{array}$ & $\begin{array}{l}\mathrm{x} \\
\mathrm{x}\end{array}$ & & & $\begin{array}{c}\text { Pavlova et al. } 2006 \\
\text { Pavlova 2007; Pavlova et al. 2013a }\end{array}$ \\
\hline Bistritsa & $\begin{array}{c}2005 \\
3.8 .2011 \\
28.9 .2011 \\
31.7 .2012 \\
18.9 .2012 \\
12.8 .2013 \\
2.10 .2014 \\
4.8 .2015 \\
5.11 .2015\end{array}$ & $\begin{array}{l}\mathrm{x} \\
\mathrm{x} \\
\mathrm{x} \\
\mathrm{x} \\
\mathrm{x} \\
\mathrm{x} \\
\mathrm{x} \\
\mathrm{x}\end{array}$ & & & $\begin{array}{c}\text { Pavlova 2007; Pavlova et al. 2013a } \\
\text { Pavlova } \text { et al. } 2014 \\
\text { Pavlova } \text { et al. } 2014 \\
\text { Pavlova } \text { et al. } 2015 \\
\text { Pavlova et al. } 2015 \\
\text { Pavlova } \text { et al. } 2015 \\
\text { Pavlova et al. } 2015 \\
\text { Georgieva } \text { et al. } 2015 \\
\text { Georgieva } \text { et al. } 2015\end{array}$ \\
\hline Borovitsa & 2005 & $\mathrm{x}$ & & & Pavlova 2007; Pavlova et al. 2013a \\
\hline Vaya & $\begin{array}{l}2005 \\
3.8 .2011 \\
2.8 .2012 \\
16.8 .2012 \\
21.8 .2013\end{array}$ & $\begin{array}{l}\mathrm{x} \\
\mathrm{x} \\
\mathrm{x} \\
\mathrm{x} \\
\mathrm{x}\end{array}$ & & & $\begin{array}{l}\text { Pavlova 2007; Pavlova et al. 2013a } \\
\text { Pavlova et al. } 2014 \\
\text { Pavlova et al. } 2015 \\
\text { Pavlova et al. } 2015 \\
\text { Pavlova et al. } 2015\end{array}$ \\
\hline Durankulashko ezero & $\begin{array}{c}2005 \\
12.7 .2012 \\
8.8 .2012\end{array}$ & $\begin{array}{l}\mathrm{x} \\
\mathrm{x} \\
\mathrm{x}\end{array}$ & & & $\begin{array}{c}\text { Pavlova 2007; Pavlova et al. 2013a } \\
\text { Pavlova et al. } 2015 \\
\text { Pavlova et al. } 2015\end{array}$ \\
\hline Krasava & 2005 & $\mathrm{x}$ & & & Pavlova 2007; Pavlova et al. 2013a \\
\hline Hristo Smirnenski na reka Yantra & 2005 & $\mathrm{x}$ & & & Pavlova 2007; Pavlova et al. 2013a \\
\hline Yovkovtsi (VT) & 2005 & $\mathrm{x}$ & & & Pavlova 2007; Pavlova et al. 2013a \\
\hline Mandra & 2005 & $\mathrm{x}$ & & & Pavlova 2007; Pavlova et al. 2013a \\
\hline Pchelina & $\begin{array}{c}2005 \\
28.9 .2011 \\
31.7 .2012 \\
18.9 .2012 \\
12.8 .2013 \\
14.10 .2013 \\
4.8 .2015 \\
5.11 .2015 \\
\end{array}$ & $\begin{array}{l}\mathrm{x} \\
\mathrm{x} \\
\mathrm{x} \\
\mathrm{x} \\
\mathrm{x} \\
\mathrm{x} \\
\mathrm{x}\end{array}$ & & & $\begin{array}{c}\text { Pavlova 2007; Pavlova et al. 2013a } \\
\text { Pavlova } \text { et al. } 2014 \\
\text { Pavlova et al. } 2015 \\
\text { Pavlova } \text { et al. } 2015 \\
\text { Pavlova } \text { et al. } 2015 \\
\text { Pavlova } \text { et al. } 2015 \\
\text { Georgieva } \text { et al. } 2015 \\
\text { Georgieva } \text { et al. } 2015\end{array}$ \\
\hline Ticha & 2005 & $\mathrm{x}$ & & & Pavlova 2007; Pavlova et al. 2013a \\
\hline Trakiets & 2005 & $\mathrm{x}$ & & & Pavlova 2007; Pavlova et al. 2013a \\
\hline Shablensko Ezero & 2005 & $\mathrm{x}$ & & & Pavlova 2007; Pavlova et al. 2013a \\
\hline Kayabsh 1 & $\begin{array}{l}\text { July2011 } \\
\text { Sept2011 } \\
\text { July2012 } \\
\text { Sept2012 }\end{array}$ & $\begin{array}{l}\mathrm{x} \\
\mathrm{x} \\
\mathrm{x} \\
\mathrm{x}\end{array}$ & $\begin{array}{l}\mathrm{x} \\
\mathrm{x} \\
\mathrm{x} \\
\mathrm{x}\end{array}$ & $\begin{array}{l}\mathrm{x} \\
\mathrm{x} \\
\mathrm{x} \\
\mathrm{x}\end{array}$ & $\begin{array}{l}\text { Teneva et al. } 2014 \\
\text { Teneva } \text { et al. } 2014 \\
\text { Teneva et al. } 2014 \\
\text { Teneva } \text { et al. } 2014\end{array}$ \\
\hline Kayabash 2 & $\begin{array}{l}\text { July2012 } \\
\text { Sept } 2012\end{array}$ & $\begin{array}{l}\mathrm{x} \\
\mathrm{x}\end{array}$ & $\begin{array}{l}\mathrm{x} \\
\mathrm{x}\end{array}$ & $\begin{array}{l}\mathrm{x} \\
\mathrm{x}\end{array}$ & $\begin{array}{l}\text { Teneva et al. } 2014 \\
\text { Teneva et al. } 2014\end{array}$ \\
\hline Ezero Momin brod & 24.5 .2013 & $\mathrm{x}$ & & & this study \\
\hline
\end{tabular}


Blato Srebarna and for the reservoirs Acheloy, Boyka, Borovitsa, Barzina, Daskal Atanasovo, Enitsa, Kamenets, Krushovitsa, Kardzhali, Mandra, Ovchi kladenets, Pchelina, Seyachi, Suedinenie, Tri kladentsi, Vucha (Traykov, 2005; Cheshmedjiev et al., 2010a; Stoyanov et al., 2012; Belkinova et al., 2014; Stoyneva, 2014) (Fig. 1). The same authors and also Dochin and Stoyneva $(2014,2015)$ indicated the "presence of toxic species (Anabaena, Aphanizomenon, Microcystis, etc.)" for the following 43 WBs: Choklyovo blato, Durankulashko ezero, Shablensko ezero, Blato Srebarna and for the reservoirs Aheloy, Aleksandrovo, Antimovo, Asparuhov val, Batak, Boyka, Barzina, Daskal Atanasovo, Dospat, Drenovets, Dabnika, Dyakovo, Hristo Smirnenski (na reka Lom), Ivaylovgrad, Kamenets, Krapets, Krushovitsa, Koprinka, Kovachitsa, Kula, Lomtsi, Mandra, Ogosta, Ovcharitsa, Pancharevo, Pchelina, Poletkovtsi, Poroy, Pyasuchnik, Rabisha, Rasovo, Seyachi, Suedinenie, Telish, Tri kladentsi, Valchovets, Vucha, Yastrebino and Zhrebchevo (Fig. 1). Toxic species were indicated as blooming in the reservoirs Kamenets, Beli Lom and Ovchi kladenets but have not been enlisted (Cheshmedjiev et al., 2010a) (Fig. 1).

\section{Environmental gradients and cyanoprokaryotes distribution}

The results of the PCA, run on the environmental variables, total phytoplankton biomass (TBS) and total cyanoprokayotes biomass (TBC) of 61 WBs are shown in Fig. 5. The cumulated relative inertia of the two first principal components reached $51.4 \%$. The main environmental gradient, associated with the first principal component, is determined by altitude and trophic status, with altitude (alt) positively correlated with Secchi depth (SD), and negatively with TN and TP. Unsurprisingly, TBS and TBC is correlated with the nutrient loading. The second principal component is mainly determined by temperature and depth (Fig. 5). Three groups of WBs are identified in this analysis: group 2 is constituted essentially by 3 closely situated coastal shallow WBs (namely Atanasovsko ezero, Vaya and Mandra), which form the well-known geographical group Bourgaski ezera) and group 3, formed by clear, oligotrophic alpine lakes and one high mountain reservoir (reservoir Beli Iskur, Bezbozhsko ezero 1, Nevenino ezero 1, Gergiysko ezero 1, Vlahinsko ezero 1, Bunderishko ezero 9 and

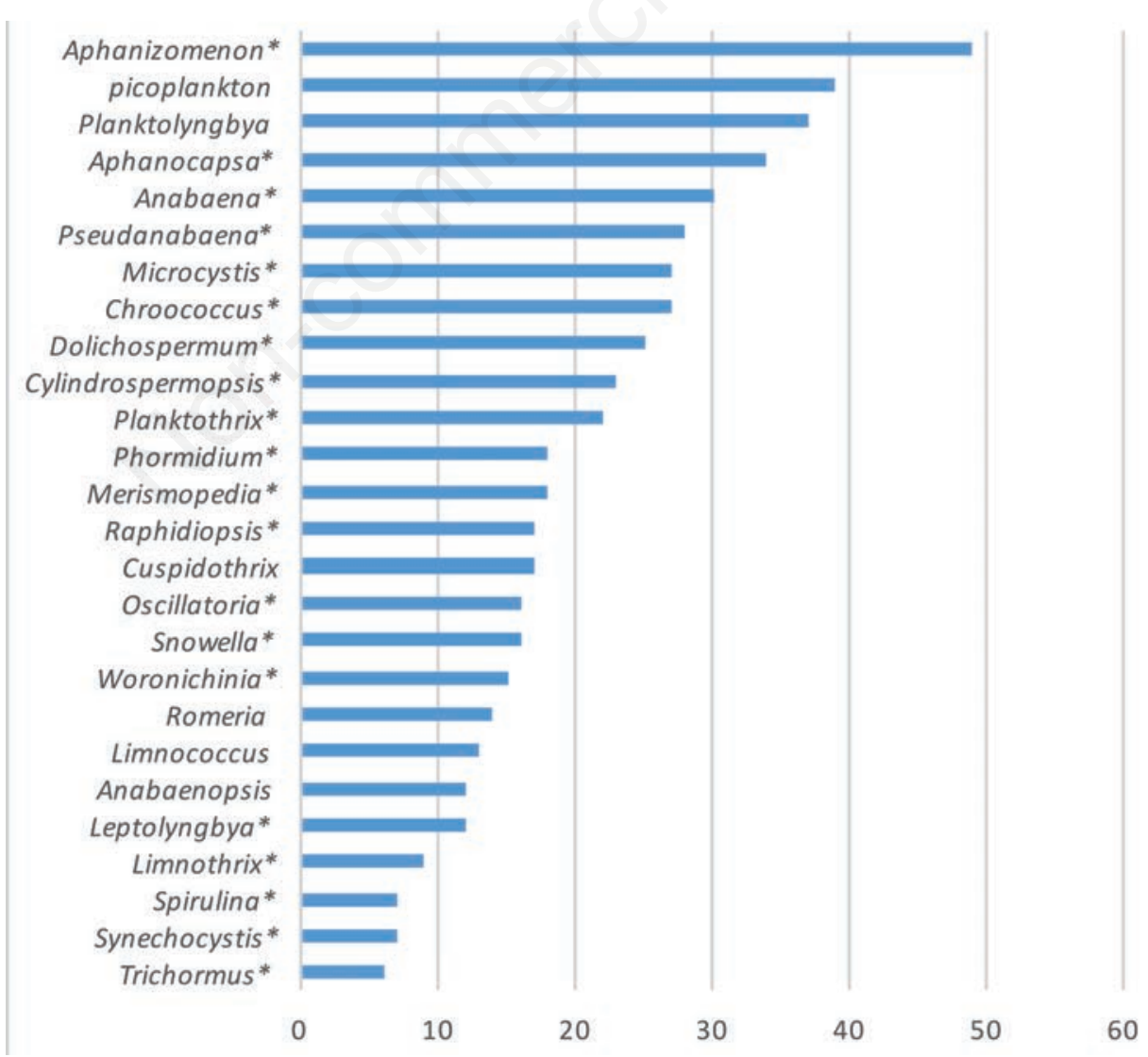

Fig. 3. Distribution of the most widespread genera of cyanoprokaryotes in the phytoplankton of Bulgarian water bodies in the period 2000-2015. 0-40, number of water bodies in which species were found; * genus found in the samples containing cyanotoxins. 
Popovo ezero 2). The central group 1 is more heterogenous, comprising mostly mid-altitude WBs with varying depth and nutrient loading, but also some shallow eutrophic lakes (close to group 2, left side of the ordination). The distribution of the WBs in Fig. 5 clearly shows the influence of geographic location on the WBs' characteristics.

The next redundancy analysis (Fig. 6), in which the dependent variables are the biomass data on 24 cyanoprokaryote genera, showed that cyanoprokaryote assemblages responded significantly to the environmental conditions, with TP as the most influential variable, followed by SD, $t$ and TN. Four main groups of genera were identified: two ( 1 and 2) on the left side of the diagram, associated with eutrophic conditions in low altitude shallow lakes, swamps and reservoirs, one (group 3) of high altitude, clear lakes; and one (4) more heterogeneous group with predominance of high conductivity conditions. Within this last are associated all rare colonial non-toxic species / Rccl/ from genera like Lemmermanniela, Coelomoron, etc. and Merismopedia (mainly M. tenuissima Lemmermann) - Mrsp, non-colonial picoplankters of Pcy group - Pcpl) and Spirulina and Glaucospira species (Spgl) with a single Phormidium (Phrm). In group 1 were Microcystis - Mcrs; Anabaena s.l. (mainly Dolichospermum) - Andl, Aphanizomenon s.1. - Aphn, Cylindrospermopsis (in this case C. raciborskii (Wołoszyńska) Seenaya \& Subba Raju only) - Clps, Plank- tothrix - Plnt, Planktolyngbya s.1. (incl. Limnolyngbya) Plnb, Romeria - Rmrr, Oscillatoria and Borzia - Osbr. Group 2 included Anabaenopsis -Anbs, PseudanabaenaPsnb, Plectonema - Plct, Leptolyngbya - Lptb. Group 3 contains Aphanocapsa - Apns, Chroococcus - Crcr, Coelosphaerium - Clsp, Snowella - Snwl, Woronichinia Wrnc) and Synechocystis (Sncs).

\section{Cyanotoxins}

The analysis of published data on cyanotoxins revealed their presence in $16 \mathrm{WBs}$ - reservoirs Bistritsa, Borovitsa, Enitsa, Kayabash 2, Krushovitsa, Mandra, Pchelina, Studena, Studen kladenets, Trakiets, Vucha, Valchovets and lakes Vaya, Durankulashko ezero, Ezero Momin brod and Shablensko ezero (Tab. 2, Fig. 1). During the summer-autumn period, microcystins LR, LA, RR, YR and similar to YR-type, nodularins, anatoxin-a and saxitoxins (from the decarbamoyl saxitoxin, gonyautotoxins II, III, B1, C1 and C2 group) in different concentrations were proved by High Performance Liguid Chromatography (HPLC, HPLC-DAD and/or HPLC-MS), enzyme-linked immunosorbent assay (ELISA) and in vitro cytotests (Tab. 2). Anatoxin was detected only once, in July 2006 in Borovitsa reservoir by HPLC (Teneva et al., 2009). Saxitoxins (STXs) were found in the reservoirs Borovitsa, Studen kladenets, Trakiets and

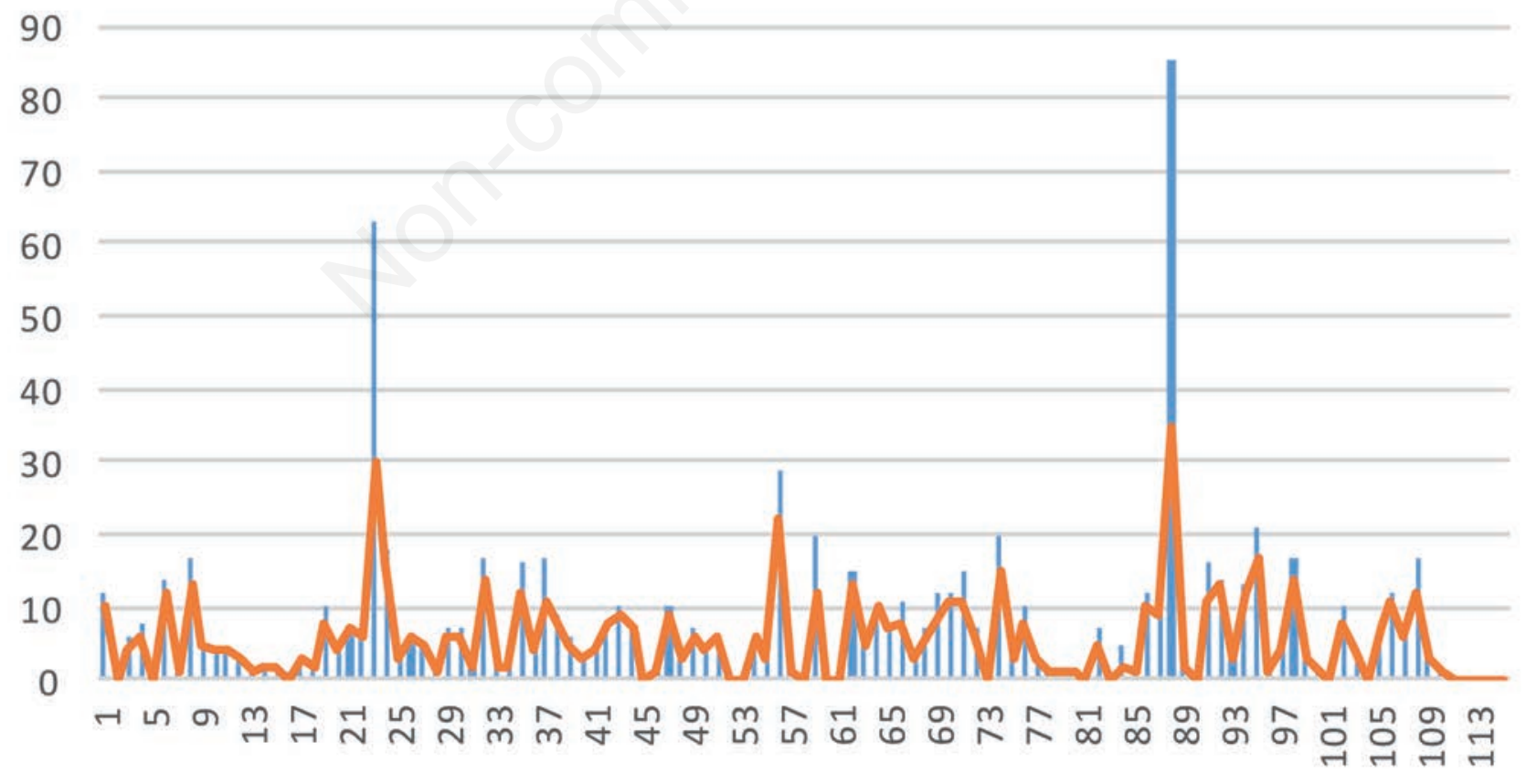

\section{Number cyanoprokaryote species $\quad$ Number cyanoprokaryote genera}

Fig. 4. Distribution of the number of species and genera of cyanoprokaryote phytoplankters in 115 Bulgarian water bodies in the period 2000-2015. 


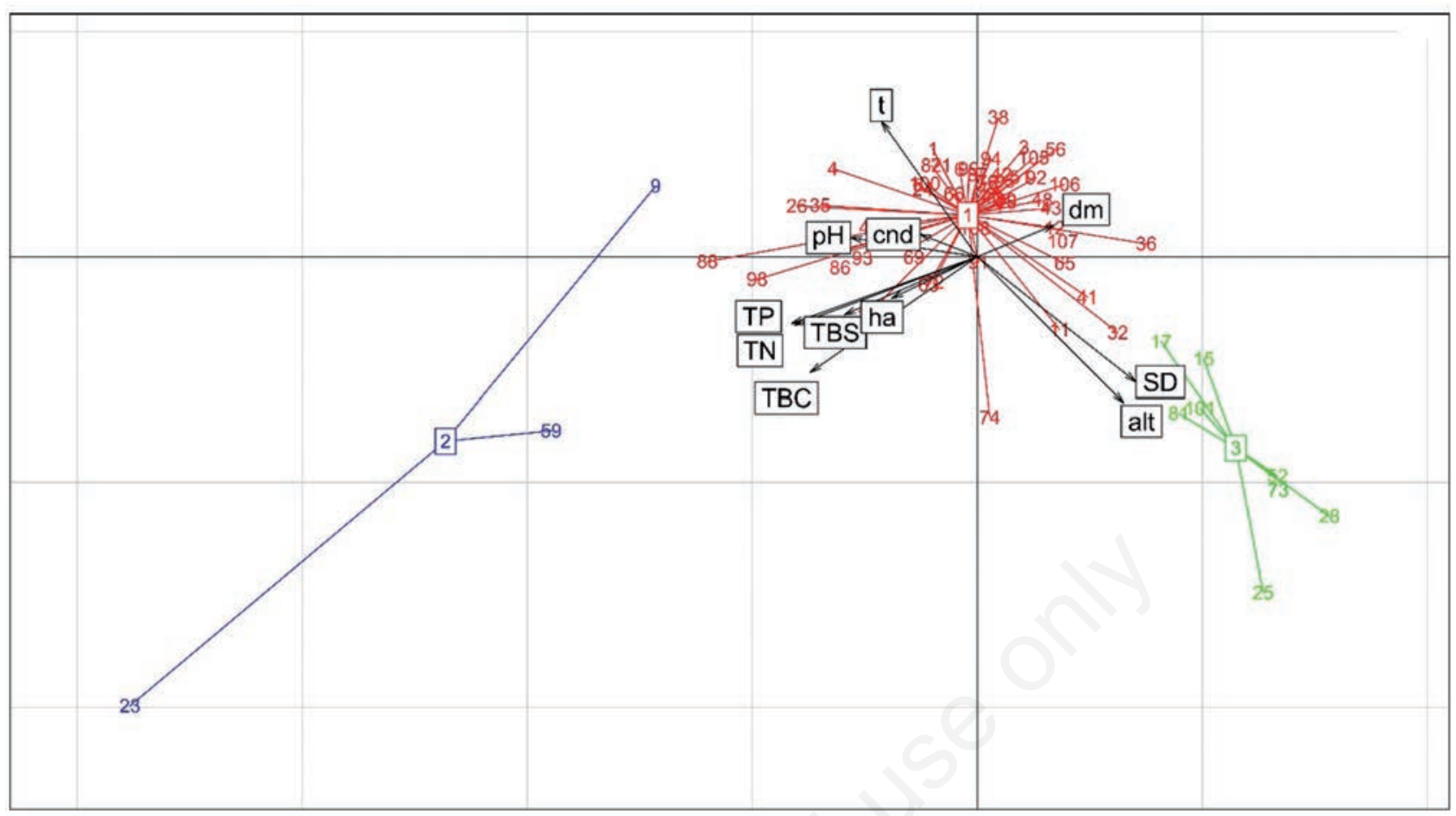

Fig. 5. Results of the principal component analysis on the environmental variables and phytoplankton/cyanoprokaryote biomass of 61 Bulgarian water bodies (WBs); ordination on the two first components (cumulative inertia: 51.4\%). Numbers and names of the WBs as in Tab. 1. t, water temperature; cond, electric conductivity; SD, Secchi depth; TP, total phosphorus; TN, total nitrogen.

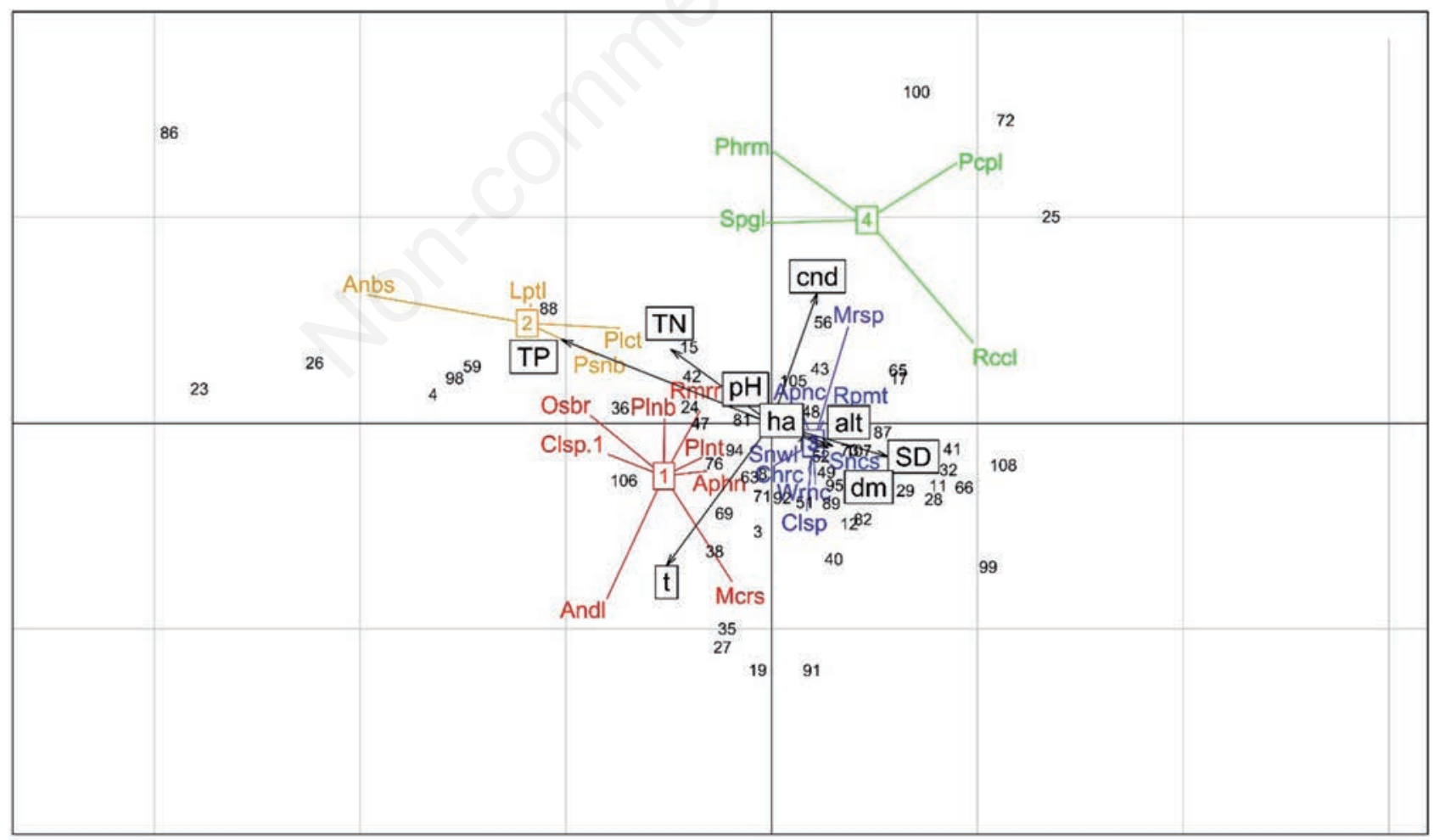

Fig. 6. Results of the redundancy analysis on the environmental variables and cyanoprokaryote genera of 61 Bulgarian water bodies (WBs); ordination on the two first components (cumulative inertia: 45.3\%). Numbers and names of the WBs as in Tab. 1. ha, area; alt, altitude; t, water temperature; cond, electric conductivity; SD, Secchi depth; TP, total phosphorus; TN, total nitrogen. 
Valchovets by Teneva et al. (2009, 2010a, 2011) and Stoyanov et al. (2012). Their concentrations varied between 0.1 and $2.5 \mu \mathrm{g} \mathrm{L}^{-1}$, except in Studen kladenets, where STXs were detected only by HPLC peaks and authors suggest that their concentrations in the water were less than their mean lower detection limit by Ridascreen ${ }^{\mathrm{TM}}$ assay $0.01 \mu \mathrm{g} \mathrm{L}^{-1}$. In the same reservoir HPLC peaks showed the presence of nodularins, but their amounts were given only as a total of microcystins/nodularins (MC/NOD) detected by ELISA (Teneva et al., 2011). In the same way, MC/NOD totals were provided for the reservoirs Borovitsa, Enitsa, Kayabash 2, Krushovitsa, Studen kladenets and Trakiets (Teneva et al., 2009, 2010a, 2011, 2014; Stoyanov et al., 2012). The types of microcystins were indicated in the publications for $10 \mathrm{WBs}$ but only for 9 of them the values have been provided (Tab. 2). According to Pavlova et al. (2006, 2007, 2013a, 2014), Pavlova (2007) and Georgieva et al. (2015) the concentrations of the different microcystin types ranged as follows: LR 0.1-8.3 $\mu \mathrm{g} \mathrm{L}^{-1}$ in water samples and 14-292 $\mu \mathrm{g} \mathrm{g}^{-1}$ in net samples, RR - 0.1-12.7 $\mu \mathrm{g} \mathrm{L}^{-1}$ in water samples and 2103.2 $\mu \mathrm{g} \mathrm{g}^{-1}$ in net samples, YR $-0.13-5.5 \mu \mathrm{g} \mathrm{L}^{-1}$ in water samples and 0.8-71.8 $\mu \mathrm{g} \mathrm{g}^{-1}$ in net samples. YR equivalent type was detected twice by HPLC-DAD in Shablensko ezero (Pavlova, 2007; Pavlova et al., 2007) and LA type was reported once from Borovitsa by Teneva et al. (2010b).

Negative results for cyanotoxins have been published by Pavlova (2007), Pavlova et al. (2007, 2013a, 2014, 2015), Teneva et al. (2014) and Georgieva et al. (2015) for $13 \mathrm{WBs}$ and for some samples from $11 \mathrm{WBs}$ with previously detected toxins (Tab. 3).

The distribution of WBs with toxins (16), the WBs with recorded blooms (14), WBs in which toxic species have been found (30) and of the not problematic WBs (54) in the 8 groups of their geographic location and vertical position is shown on Fig. 7.

According to the above cited references, 52 algae and some akinetes have been discovered in the water samples with detected toxins. Among them 45 from 21 genera were identified at species or generic level. The information on the number of their findings in toxic samples, the number of WBs, from which these samples have been collected together with the range of species biomass exactly in these samples, types of toxins, methods used and sources are summarized in Tab. 4. Figs. 2 and 3 illustrate the distribution of these species and genera in Bulgarian WBs during the studied period.

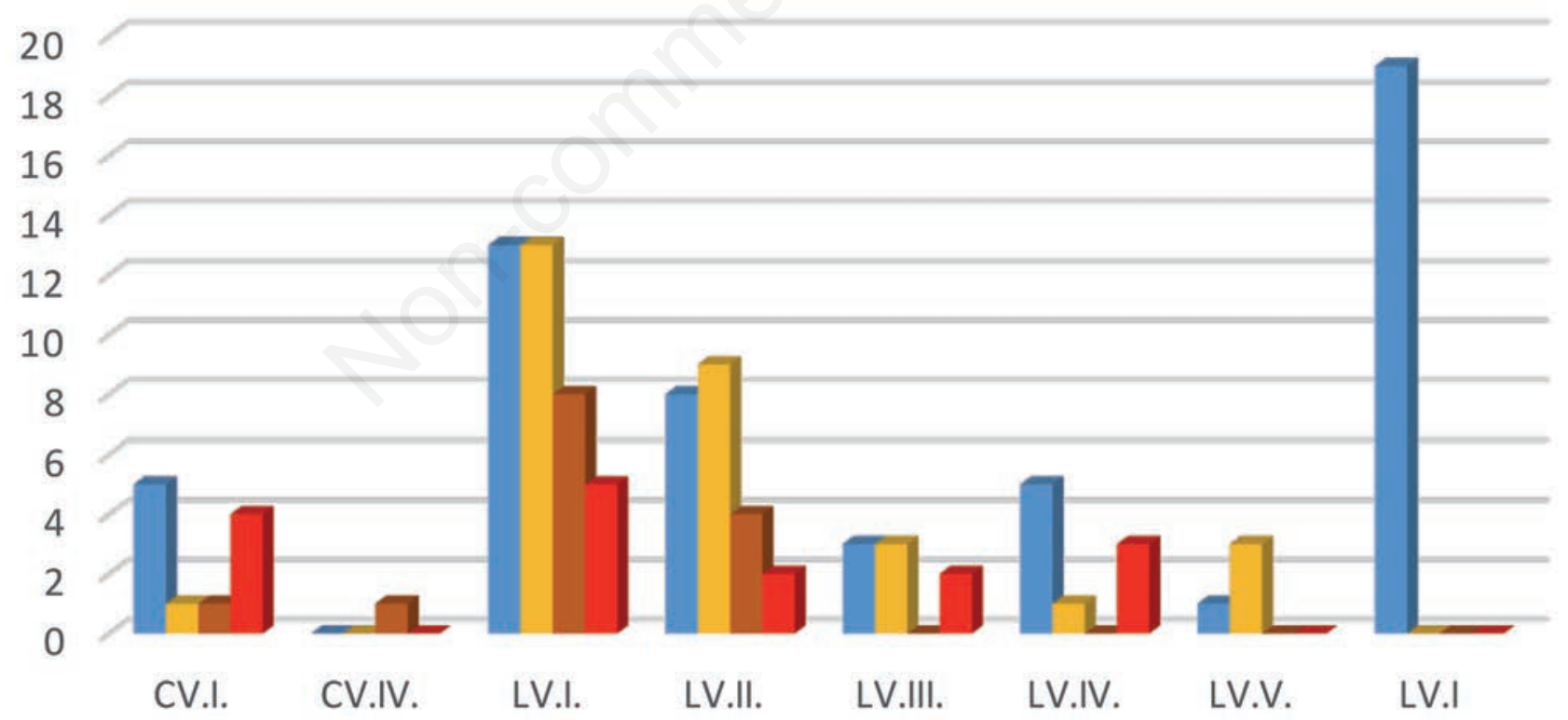

Not problematic WB

WB with cyanoblooms
WB with presence of toxic species

WB with detected toxins

Fig. 7. Distribution of water bodies (WB) with toxins, the WBs with recorded blooms, WBs in which toxic species have been found and of the not problematic WBs in the 8 phyla of their geographic location and vertical position (CV.I-LV.VI). Colours are on conformity with colours on Fig. 1, for the description of CV.I-LV.VI phyla see the text. 


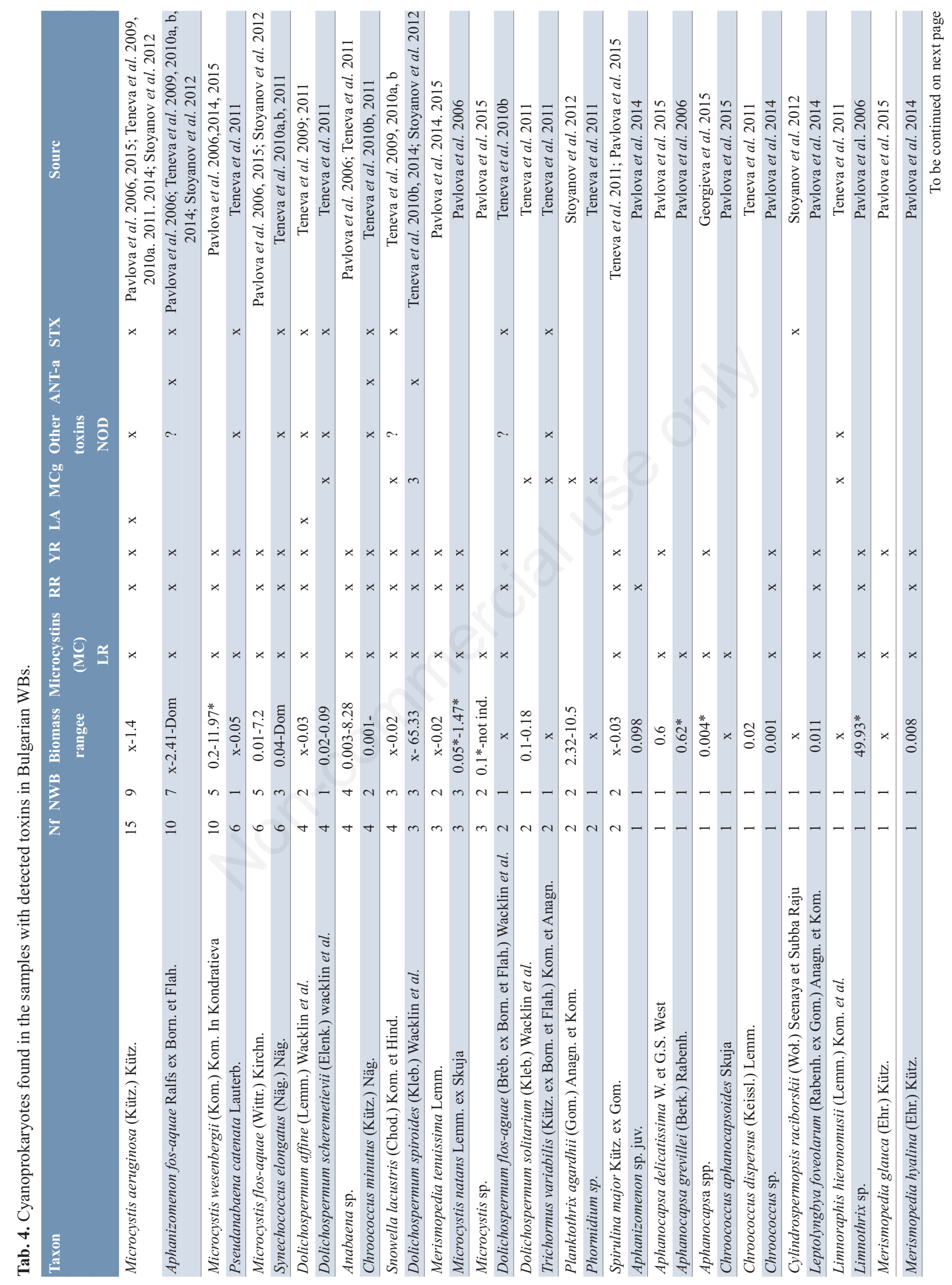




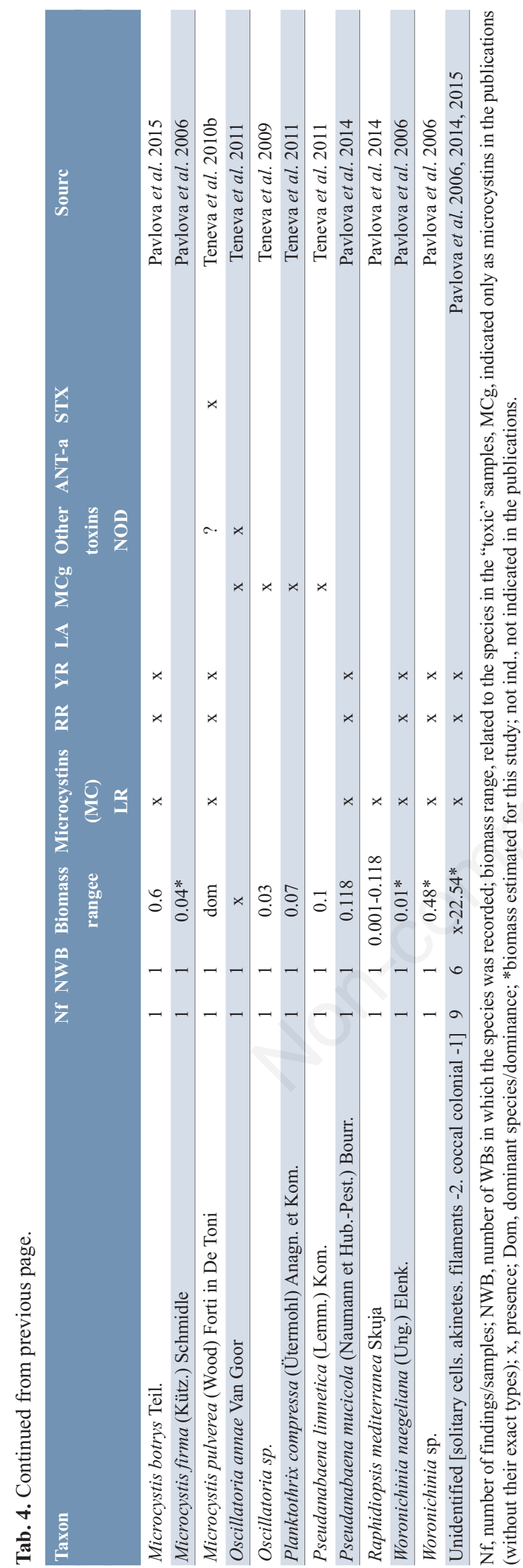

\section{DISCUSSION}

The analysis of data on phytoplankton species composition revealed that, in spite of being quite heterogeneous, they are generally available for 111 from 115 purposively studied WBs included in Tab. 1, except concrete data for the reservoirs Stoychovtsi, Karaisen, Luzhenska Bara and Aleksandrovo. However, the occurrence of cyanoprokaryotes in the last reservoir was documented as "presence of toxic species" (Cheshmedjiev et al., 2010a; Fig. 1). In all samples proceeded by us, cyanoprokaryotes were not found in 11 alpine lakes (Bunderishko ezero 9, Musalensko ezero 3, Ezero Bliznaka, Ezero Bubreka, Ezero Okoto, Ezero Sulzata, Kremensko ezero 2, Marichino ezero 2, Marichino ezero 3, Popovo ezero 2 and Vlahinsko ezero 1) and in the occasionally sampled reservoirs Yarlovets and Zhernov. Therefore, we argue that $99 \mathrm{WBs}$ contain different number and amount of cyanoprokaryotes. With the total of 210 taxa found, they represent only $3.8 \%$ of the algal biodiversity of the country estimated as ca. 5,500 taxa by Stoyneva (2014), but comprise $36.4 \%$ from all 576 cyanoprokaryotes (Stoyneva et al., 2016). Coccal cyanoprokaryotes were the richest group both in species (85) and genera (31), while the number of heterocytous species and genera was the lowest. This result is on general conformity with the shallow and eu- to hypertrophic character of most studied WBs, in which, according to our unpublished results, nitrogen was not a limiting factor (N/P ranged between 7 and 110). Similar conclusion could be made according to the data in the publications by Teneva et al., 2010a; Belkinova et al., 2014; Pavlova et al., 2015; Stoyanov et al., 2016, etc.

The highest taxonomic diversity, expressed as number of species and genera, was detected in two WBs: Blato Srebarna (85/35) and Vaya (63/30) (Fig. 4). Due to their high importance for conservation of rare and threatened species of national, European and global significance (Michev and Stoyneva, 2007; Vassilev et al., 2013), these two shallow lakes have been intensively studied before and during the analyzed period, and always have been outlined for their rich algal diversity (Michev et al., 1998; Stoyneva, 1998a, 1998b, 2003, 2014, 2015; Georgiev, 2012; Dimitrova et al., 2014a, 2014b). However, the same authors outlined the negative trends in their development with enhanced eutrophication, cyanoprokaryote blooms (incl. the rare equilibrium states dominated by cyanoprokaryotes) formed by potentially toxic species. The negative effects of increased eutrophication due to long-term cage fish farming were stressed also for the mountain reservoirs Dospat and Kardzhali, where among the newly appeared group of cyanoprokaryotes the harmful Aphanizomenon flos-aquae, Dolichospermum spiroides and Planktothrix rubescens (De Candolle ex Gomont) Anagnostidis et Komárek participated in the dominant complexes (Dochin and Stoyneva, 2014, 2015; Dochin 2015). 
The analysis of the distribution of species and genera points to 2 species (Aphanizomenon flos-aquae and Cylindrospermopsis raciborskii) and 11 genera as being the most widespread in the country (Planktothrix, Cylindrospermopsis, Dolichospermum, Chroococcus, Microcystis, Pseudanabaena, Anabaena, Aphanocapsa, Planktolyngbya and Aphanizomenon; Figs. 2 and 3). Except for Chroococcus, Aphanocapsa and Planktolyngbya they have been commonly pointed as principally responsible for forming blooms (e.g. Oliver and Ganf, 2002) mainly due to presence of gas vesicles. Among the total of 69 genera found, at least 29 are known as cyanotoxin producers (Metcalf and Codd, 2012; Pettersson and Pozdnyakov 2013). If the genera Chrysosporum and Sphaerospermopsis, which relatively recently have been separated from Anabaena (Komárek, 2013 and references therein), are considered, this number will increase to 31 , or $45 \%$ from all found in the country. The frequency of findings of all these potentially toxic genera in combination with the spreading of cyanoprokaryote blooms (Fig. 1) are logically related with the findings of different types and amounts of cyanotoxins in Bulgarian WBs (Tab. 2).

The results of multivariate analysis show the consistency of the WBs classification based on geographic position and altitude (as first steps proposed in the hierarchical classification of Bulgarian wetlands by Michev and Stoyneva, 2007), along with in-lake characteristics as depth and nutrient content. Total phytoplankton biomass, total cyanoprokaryote biomass, as well as cyanoprokaryote assemblages showed a strong response to the environmental variables, with an expected major influence of TP.

The redundancy analysis identified four groups of genera in relation to WBs, among which groups 3 and 4 are more heterogenous in comparison with groups 1 and 2. Group 3 contains realtively small colonial embedded in mucilage coccal genera (Aphanocapsa, Chroooccus, Coelosphaerium, Snowella, Woronichinia) and non-colonial coccal Synechocystis which are classical phytoplankters in various types of WBs. Despite their general ubiquity and abundance in a wide spectrum of trophic conditions, these non-bloom formers are not a well-known group, particularly in relation to their ecology (Stockner et al., 2002). In our opinion, the presence of all these small coccal genera in group 3 reflects well the heterogenous character of its WBs in terms of geographic location, morphometry and way of use, but united by the prevalence of meso- to oligotrophic conditions.

Within the group 4 with predominantly high conductivity conditions, characterized by extremely low TBC, are associated diverse and most rarely (in this study) distributed smallest coccal cyanoprokaryotes (all rare colonial non-toxic species, Merismopedia, non-colonial picoplankters of Pcy group), very thin filamentous rare Spirulina and
Glaucospira species with a single (and most probably benthic) Phormidium. All of them are generally considered as non-blooming cyanoprokaryotes (Stockner et al., 2002). By contrast, most genera well known for their ability to form water blooms due to presence of gas vesicles (Oliver and Ganf, 2002) were in group 1: Microcystis; Anabaena s.l. (mainly Dolichospermum), Aphanizomenon s.l., Cylindrospermopsis and Planktothrix. The other genera in group 1 are filamentous without gas vesicles: classical planktonic thin Planktolyngbya s.l., generally short-celled fine Romeria and occasionally distributed in this data set short-celled Oscillatoria and Borzia. As it could be seen, besides the very rare and therefore non-representative Osbr, the "exception" from this filamentous group 1 is the coccal colonial Microcystis. However, the "filamentous" character of another participant in group 1 - Romeria - is still not proved and its coccal nature is in discussion (Komárek and Anagnostidis, 2005). Common feature of the strangers (Microcystis, Planktolyngbya and Romeria) in group 1 is the presence of well-developed homogenous colourless mucilage. The irregular presence of gas vesicles in combination with wide, but fine mucilage envelopes is known also for Anabaenopsis and Pseudanabaena, which are representatives of group 2. The group includes also the thin (1-2 $\mu \mathrm{m})$ filamentous rarely branched Plectonema and straight filamentous Leptolyngbya representatives, most of which have not been determined at species level due to their small dimensions and problematic taxonomy (Komárek and Anagnostidis, 2005). The stranger in the group is the heterocytous and capable of bloom-forming Anabaenopsis. However, a capability for nitrogen fixation was proved for some Leptolyngbya species also (e.g. Stal, 2012). According to our recent knowledge, very few data confirm the toxic abilities of the genera in group 2 (except for Anabaenopsis milleri Voronichin, which was not found in our studies), which comprises coastal and inland lowland lakes and reservoirs with generally hypertrophic character. By contrast, the genera from group 1, and its core representatives (Aphanizomenon, Cylindrospermopsis, Microcystis and Planktothrix) in particular were repeatedly pointed as bloom-forming and toxin producing genera related mainly with eutrophic conditions and were also the key players in toxic samples, detected in Bulgarian waters (Fig. 3; Tab. 2). They were found among the genera with broadest distribution in the country (Fig. 3). The common traits of the taxa belonging to this group are the affinity for eutrophic conditions and the presence of gas vesicles, which provide buoyancy control of filament and colonies, allowing efficient vertical migration in the water column of relatively shallow lakes which present alternation of periods of stratification and mixing (Reynolds, 2006). Accordingly, the WBs of group 1 are relatively small, inland lowland to low-mountain, eu- to hypertrophic reservoirs.

The samples with detected cyanotoxins were from 16 
WBs (Tab. 2) and contained 44 cyanoprokaryotes identified to species or genus level (Tab. 4). Their distribution in Bulgaria, with a few exceptions, is relatively broad (Figs. 2 and 3). The results from this study confirm the trend for their fast spread in the country outlined especially in relation to the invasive species like Cylindrospermopsis raciborskii (Stoyneva, 2015; Kokocinski et al., in press). Most of these 44 species and 21 genera have been repeatedly reported as real or potential toxin producers but for some of them discussions are still running (e.g. for Microcystis species as summarized in Šejnohová and Maršálek, 2012). It is out of scope of this study to go deep in the contradictory opinions, which have to be interpreted with caution, moreover for details in relation with findings in Bulgaria we can refer to our previous papers (Pavlova et al., 2006, 2014, 2015). Summarizing the results from this study, we could outline that exactly one of the most often discussed species - $M$. wesenbergii - was the most often recorded species in toxic samples (Tab. 4). In the same time, Pseudanabaena mucicola (Naumann et Huber-Pestalozzi) Bourrelly, which is a relatively regular endophyte in $M$. wesenbergii, was reported only once as associated with cyanotoxin detection. Some of the species in Tab. 4 are identified only at genus level, or are known for problematic identification, and therefore discussion on them is not relevant without proper documentation, which is not available in the published papers. It has to be noted also, that other cyanoprokaryotes, known for their potential to produce toxins, were found in the country. For example, Nodularia spumigena Mertens ex Bornet ex Flahault was reported from three temporary WBs on Belene island in The Danube (Beshkova and Botev, 2004), but the study was not supplied with toxin analysis. Obviously, aimed studies on toxin groups other than microcystins, combined with permanent toxin monitoring will reveal more objective picture of presence/absence of different cyanotoxins and species related with them. A cooccurrence of other algae could also have an effect, and even provide a source, for some of the toxins detected (e.g. pyrrhophytes for saxitoxins). Since long time it is well-known that cyanoprokaryote dominance (and blooms in particular) is strongly affected by complex interactions between lake morphometry, water temperature, underwater light availability, nutrient supply and total food-web structure and can not be viewed independently from all other members of phytoplankton (Harris, 1986; Reynolds, 1987, 2006; Dokulil and Teubner, 2000 among the many others). Therefore, we would like to outline the necessity for providing data in future publications on the total species composition for the samples and WBs with detected cyanotoxins or harmful blooms.

In the temperate country like Bulgaria it is not surprising that cyanotoxins were detected in the water samples from summer-autumn periods, when the abundance of cyanoprokaryotes is normally the highest for the year. However, the comparison of Tabs. 2 and 3 clearly shows that occurrence of toxins is intermittent in Bulgarian WBs. Conclusions about the correlations between finding of cyanotoxins and relevant species or total sample biomass are hardly possible due to lack of concrete published data for all cases. The only statement which could be done is that cyanotoxins were detected within a broad range of algal abundance (Tabs. 2 and 4). In some cases, Dolichospermum spiroides (Klebahn) Wacklin et al., Limnothrix sp., Microcystis wesenbergii, Planktothrix agardhii (Gomont) Anagnostidis et Komárek, Anabaena sp. and some unidentified algae had high biomass values in samples with detected toxins (Tab. 4). But toxins were detected even when species were found in low, even negligible, concentrations (the cases of Borovitsa, Valchovets, Studena, etc. in Tab. 2). The topic was discussed by Pavlova et al. (2006) and Teneva et al. (2009), who supposed that such cyanotoxin quantities were due to blooms, which occurred in the WBs before the sampling. Therefore, it is necessary to outline again that finding of cyanotoxins in waters is not always related with obvious blooms. Moreover, the term bloom and its lower borders remained poorly defined (Oliver and Ganf, 2002). However, the result obtained is important for rising the public awareness of the cyanoblooms, which could have long consecutive effect on the ecosystem health and humans.

In spite of heterogenous way of representing the results on cyanotoxin amounts, it could be stated that in most cases, and in the drinking-water reservoirs in particular, the concentration of microcystin LR is lower than WHO's (1998) limit of $1 \mu \mathrm{g} \mathrm{L}^{-1}$ (Tab. 2). The general amount and types of microcystins and other cyanotoxins are on conformity with the results published for the closest neighboring countries Macedonia, Serbia, Romania, Turkey and Greece, as it was outlined by Pavlova et al. (2015). However, the fact of their findings in 16 WBs (among which 3 are important drinking-water reservoirs, 2 are water supply reservoirs, 3 are used for irrigation and 8 are recreational sites for sports and fishing) on the background of more recorded cyanoprokaryote blooms and broad spread of toxic species in Bulgaria (Figs. 1, 2 and 3) is strong enough to alarm both scientists and responsible authorities at national level. Moreover, the analyses of all data clearly show that during the last 15 years cyanoprokaryotes were not restricted in distribution in the lowlands and plains but started to invade WBs with higher altitudes, i.e. WBs situated in kettles and low mountains (Fig. 7). The outlining of the necessity of stronger recognition of the problem in the country and rising of the public awareness made here is not the first, just the opposite - almost each of the papers on the topic published in the analyzed period had this statement as a main conclusion since there is no doubt that the peculiar and otherwise fascinating group of cyanoprokaryotes is a 
real hazardous factor for human and aquatic ecosystem health in Bulgaria.

\section{CONCLUSIONS}

All results from studies carried in summer- autumn periods of the last 15 years (2000-2015) in 120 Bulgarian WBs different in location, morphometry and trophic status (incl. drinking-water reservoirs, reservoirs for water supply, irrigation and energy production reservoirs, recreational lakes and sites of nature conservation importance), gathered from 35 publications, showed that in 30 of them toxic species were found. Cyanoprokaryote blooms were recorded in $14 \mathrm{WBs}$ and in 16 cyanotoxins (microcystins, nodularins and saxitoxins) were detected, and cyanoprokaryote diversity was quite high (210 taxa of 60 genera). Toxin concentration ranged between 0.1 and 26.5 $\mu \mathrm{g} \mathrm{L}^{-1}$ in water samples and between 10.9 and $1070 \mu \mathrm{g}$ $\mathrm{g}^{-1}$ (d.w.) in concentrated (net) samples. Despite the fact that microcystins were not found in all studied WBs and that the recorded levels were still lower in comparison with some other European countries and with WHO's threshold for microcystin LR, the fact of cyanotoxin detection in 3 drinking-water reservoirs and cyanoprokaryote occurrence in low mountain WBs could serve as an alert for the need of recognition of cyanotoxins as a new health risk factor in the country. Therefore, permanent monitoring with identification of toxins in WBs at risk and activities for limitation and control of toxic blooms are urgently needed, in combination with increase of the attention to the effects of cyanotoxins on both human health and health of aquatic ecosystems in Bulgaria. We also stress the need for a more comprehensive monitoring of the problematic WBs and of their watershed - including all key environmental variables (hydrology, nutrient loading and meteorology) and detailed phytoplankton surveys in order to improve water quality management and identify the measures to be taken to reduce the risks associated with cyanoprokaryote blooms.

\section{ACKNOWLEDGMENTS}

The authors would like to acknowledge the European Cooperation in Science and Technology, COST Action ES 1105 "CYANOCOST- Cyanobacterial blooms and toxins in water resources: Occurrence, impacts and management" and Bulgarian national supporting financing by the Scientific Fund of the Ministry of Education and Science (projects DKOST 01/2-11.08.2016 and DKOST $10 / 2-19.08 .2016$ ) for adding value to this study through networking and knowledge sharing with European experts and researchers in the field.

A part of the results, taken from Stoyneva (2014), was obtained during EMERGE project of EC Framework V, MEWs project on Srebarna Lake Monitoring (19942003), project of World Bank and Zeleni Balkani for Management Plan of Pomorie Wetland, monitoring studies of Bulgarian lakes of Ecotan EOOD commissioned by the EEA of MEWs of Bulgaria and studies on chosen oligotrophic lakes in Pirin Mts, commissioned by Pirin National Park.

The authors are thankful to the colleagues Assoc. Prof T. Michev, Assist. B. Michev, Mr N. Mihov, Mr R. Rusev, Mr. P. Simeonov, Assoc. Prof. Dr P. Zhelev, Dr A. Asenov, Main Assist. Dr P. Ivanov and Assoc. Prof. Dr I. Traykov for collecting samples and environmental data out of the frame of the above mentioned projects.

Special thanks are due to Mrs. A. Lazarova from the National Health Centre for analyzing of TP and TN in water samples, and to two anonymous reviewers for helpling improve the manuscript.

\section{REFERENCES}

Belkinova D, Gecheva G (eds.), 2013. [Biological Analysis and Ecological Assessment of the types of surface waters in Bulgaria].[Book in Bulgarian]. Plovdiv University "Paisiy Hilendarski” Publishing, Plovdiv: 201 pp.

Belkinova D, Mladenov R, Dimitrova-Dyulgerova I, Cheshmedjiev S, Angelova I, 2007. Phytoplankton research in Kurdzhali Reservoir. Phytol. Balc. 13:47-52.

Belkinova D, Padisák J, Gecheva G, Cheshmedjiev S, 2014. Phytoplankton based assessment of ecological status of Bulgarian lakes and comparison of metrics within the water framework directive. Appl. Ecol. Environ. Res. 12:83-103.

Beshkova M, Kalchev R, Vasilev V, 2012. Taxonomical and functional structure, species diversity and abundance of phytoplankton assemblages of the Srebarna Lake in relation to changes of ecological conditions, p. 39-56. In: Y. Uzunov, B.B. Georgiev, E. Varadinoiva, N. Ivanova, L. Pehlivanov and V. Vasilev (eds.), Ecosystems of the Biosphere Reserve Srebarna Lake. Professor Marin Drinov Academic Publishing House.

Beshkova M, Kalchev RK, Vassilev V, Tsvetkova RL, 2008a. Changes of the phytoplankton abundance and structure in the Biosphere Reserve Srebarna (Northeastern Bulgaria) in relation to some envronmental variables. Acta Zool. Bulg. Suppl. 2:166-174.

Beshkova MB, Botev IS, 2004. Phytoplankton community structure of three temporary wetlands on Belene Island (Bulgarian sector of the Danube River). Phytol. Balc. 10:11-19.

Beshkova MB, Kalchev RK, Kalcheva HV, 2008b. Phytoplankton and bacterioplankton in three reservoirs (North East Bulgaria) accepted as a potential referent sites according the Water Framework Directive of EU. Acta zool.bulg. Suppl. 2:155-164.

Beshkova MB, Kalchev RK, Kalcheva HV, 2014. Phytoplankton in the Zhrebchevo Reservoir (Central Bulgaria) before and after invasion of Dreissena polymorpha (Mollusca: Bivalvia). Acta Zool. Bulg. 66:399-409. 
Callieri C, Stockner JG, Cronberg G, 2012. Freshwater picocyanobacteria: single cells, microcolonies and colonial forms, p. 229-270. In: B.A. Whitton (ed.), The ecology of Cyanobacteria II. Their diversity in space and time. Springer.

Carmichael WW, 1994. The toxins of cyanobacteria. Sci. Am. 270:64-72.

CEN EN 15204, 2006. Water quality - Guidance standard on the enumeration of phytoplankton using inverted microscopy (Utermöhl technique): $42 \mathrm{pp}$.

Cheshmedjiev S, Belkinova D, Mladenov R, Dimitrova-Dyulgerova I, Gecheva G, 2010a. Phytoplankton based assessment of the ecological status and ecological potential of lake types in Bulgaria. Biotechnol. Biotec. Eq. 24:14-25.

Cheshmedjiev S, Gecheva G, Belkinova D, Varadinova E, Dimitrova-Dyulgerova I, Mladenov R, Soufi R, Pavlova M, Pehlivanov L, 2013. Assessment of ecological status and preliminary results on reference conditions in alpine glacial lakes (Bulgaria) - A contribution to the implementation of the Water Framework Directive. Biotechnol. Biotec. Eq. 27:3522-3528.

Cheshmedjiev S, Karagiozova T, Michailov M, Valev V, 2010 b. Revision of river and lake typology in Bulgaria within ecoregion 12 (Pontic Province) and ecoregion 7 (Eastern Balkans) according to the Water Framework Directive. Ecologia Balkanica 2:75-96.

Chorus I, Bartram J (eds.), 1999. Toxic cyanobacteria in water. A guide to their public health consequences, monitoring and management. WHO, Publ. E \& FN Spon, London: 416 pp.

Codd GA, 1994. Cyanobacterial (blue-green algal) toxins in marine and estuarine waters. Scott. Assoc. Mar. Sci. Newslett. 9:7.

Codd GA, 1995. Cyanobacterial toxins: occurrence, properties and biological significance. Water Sci. Technol. 32: 49-156.

Codd GA, Azevedo SMFO, Bagchi SN, Burch MD, Carmichael WW, Harding WR, Kaya K, Utkilen HC, 2005b. CYANONET: A Global Network for Cyanobacterial Bloom and Toxin Risk Management. Initial Situation Assessment and Recommendations, Technical Documents in Hydrology 76, UNESCO, Paris: 138 pp.

Codd GA, Bell SG, Kaya K, Ward CJ, Beattie KA, Metcalf JS, 1999. Cyanobacterial toxins, exposure routes and human health. Eur. J. Phycol. 34:405-415.

Codd GA, Morrison LFM, Metcalf JS, 2005a. Cyanobacterial toxins: risk management for health protection. Toxicol. Appl. Pharm. 203:264-272.

Dimitrova RE, Nenova EP, Uzunov BA, Shihiniova MD, Stoyneva MP, 2014a. Phytoplankton abundance and structural parameters of the critically endangered protected area Vaya Lake (Bulgaria). Biotechnol. Biotec. Eq. 28:871-877.

Dimitrova RE, Nenova EP, Uzunov BA, Shihiniova MD, Stoyneva MP, 2014b. Phytoplankton composition of Vaya Lake (2004-2006). Bulg. J. Agric. Sci. 20. Suppl. 1:165-172.

Dochin KT, 2015. [Seasonal dynamics and species composition of the phytoplankton in the reservoirs Kardzhali and Dospat].[PhD Thesis in Bulgarian], Sofia University "St Kliment Ohridski", Faculty of Biology.

Dochin KT, Stoyneva MP, 2014. Effect of long-term cage fishfarming on the phytoplankton biodiversity in two large Bulgarian reservoirs. Ber. nat.-med. Verein Innsbruck 99:49-96.

Dochin KT, Stoyneva MP, 2015. Phytoplankton of the reservoir "Dospat" (Rodopi Mts, Bulgaria) as indicator of negative trend in reservoir development due to long-term cage fish farming. Ann. Sof. Univ. Fac. Biol. Book 2 - Botany 99:47-60.

Dokulil MT, Teubner K, 2000. Cyanobacterial dominance in lakes. In: P.B. Hamilton, H. Kling and M.T. Dokulil (eds.), Cyanoprokaryotes and Chlorophytes across lake trophic states. Hydrobiologia 438:1-12.

European Commission, 2000. Directive of the European Parliament and of the Council 2000/60/EC establishing a framework for community action in the field of water policy. Official Journal L 327:1-72.

Georgiev B, 2012. Biodiversity of Srebarna Biosphere Reserve: An overview, p. 13-24. In: Y. Uzunov, B.B. Georgiev, E. Varadinoiva, N. Ivanova, L. Pehlivanov and V. Vasilev (eds.), Ecosystems of the Biosphere Reserve Srebarna Lake. Professor Marin Drinov Academic Publishing House.

Georgieva V, Pavlova V, Bratanova Zl, 2015. Hygienic assessment of the water reservoirs "Studena", "Bistritsa" and "Pchelina", based on performed hydrobiological analysis and determination of some toxins. Bulg. J. Public Health 7:3-13.

Graham LE, Graham JM, Wilcox LW, 2009. Algae. Benjamin Cummings, San Francisco: 616 pp.

Griffiths HI, Kryštufek B, Reed JM, 2004. Balkan biodiversity. Pattern and process in the European Hotspot. Kluwer, Dordrecht: $357 \mathrm{pp}$.

Guiry MD, Guiry GM, 2016. AlgaeBase. World-wide electronic publication, National University of Ireland, Galway. http://www.algaebase.org

Harris GP, 1986. Phytoplankton ecology. Structure, function and fluctuation. Chapmann and Hall, London, New York: 384 pp.

Huisman J, Matthijs HCP, Visser PM, 2005. Harmful cyanobacteria. Springer, The Netherlands, Dordrecht: $241 \mathrm{pp.}$

Kalchev R, Botev I, Hristozova M, Naidenow W, RaikowaPetrova G, Stoyneva M, Temniskova-Topalova D, Trichkova T, 2004. Ecological relations and temporal changes in the pelagial of the high mountain lakes in the Rila Mountains (Bulgaria). J. Limnol. 63:90-100.

Kokociński M, Akçaalan R, Salmaso N, Stoyneva M, Sukenik A, 2016. Expansion of alien/invasive cyanobacteria. In: J. Meriluoto, G.A. Codd and L. Spoof (eds.), Handbook of Cyanobacterial Monitoring and Cyanotoxin Analysis, First Edition. John Wiley \& Sons (In press).

Komárek J, 2013. Cyanoprokaryota. 3rd Part: Heterocytous genera. In: B. Büdel, L. Krienitz, G. Gärtner, and M. Schagerl (eds.), Süßwasserflora von Mitteleuropa, 19(3), Elsevier: $1130 \mathrm{pp}$.

Komárek J, Anagnostidis K, 1999. Cyanoprokaryota. 1 Teil: Chroococcales. In: H. Ettl, G. Gärtner, H. Heynig and D. Mollenhauer (eds.), Süßwasserflora von Mitteleuropa, 19(1), G. Fischer, Jena: 549 pp.

Komárek J, Anagnostidis K, 2005. Cyanoprokaryota. 2nd Part: Oscillatoriales. In: B. Büdel, L. Krienitz, G. Gärtner and M. Schagerl (eds.), Süßwasserflora von Mitteleuropa, 19(2), Elsevier: 758 pp.

Komárek J, Kastovsky J, Jezberová J, 2011. Phylogenetic and taxonomic delimitation of the cyanobacterial genus Aphanothece and description of Anathece gen. nov. Eur. J. Phycol. 46:315-326.

Legendre P, Gallagher ED, 2001. Ecologically meaningful transformations for ordination of species data. Oecologia 129:271-280. 
Maršálek B, Bláha L, Hindák F, 2000. Review of toxicity of cyanobacteria in Slovakia. Biologia 55:645-652.

McNeil J, Barrie FR, Bruck WR, Demoulin V, Greuter V, Hawksworth DW, Herendeen PS, Knapp S, Marhold K, Prado J, Prud'homme van Reine WF, Smith GF, Wiersema JH, Turland NJ (eds.), 2012. International Code of the Nomenclature for algae, fungi and plants (Melbourne Code). Regnum Vegetabile 154. Koeltz Scientific Books: 240 pp.

Meriluoto J, Codd GA (eds.), 2005. TOXIC: Cyanobacterial monitoring and cyanotoxin cnalysis. Åbo Akademi University Press, Turku: 149 pp.

Metcalf JS, Codd GA, 2012. Cyanotoxins, p. 651-675. In B.A. Whitton (ed.), Ecology of Cyanobacteria II: Their diversity in space and time, Springer.

Michev TM, Georgiev BB, Petrova AV, Stoyneva MP (eds.), 1998. Biodiversity of the Srebarna Biosphere Reserve. Checklist and bibliography. Co-publ. Context \& Pensoft, Sofia: $130 \mathrm{pp}$.

Michev TM, Stoyneva MP (eds.), 2007. Inventory of Bulgarian Wetlands and Their Biodiversity. Part 1: Non-Lotic Wetlands. Publishing House Elsi-M, Sofia: 364 pp.

Michev TM, Stoyneva MP, 2005. Red list of Bulgarian wetlands: conception, creation and application. Ann. Sofia Univ. 96: 71-76.

Mischke U, Carvalho L, McDonald C, Skjelbred B, Solheim AL, Phillips G, de Hoyos C, Borics G, Moe J, Pahissa J, 2011. WISER: Deliverable D3.1-2: Report on phytoplankton bloom metrics. Project co-funded by the European Commission within the Seventh Framework Programme (20072013) Dissemination Level: 48 pp.

Oliver RL, Ganf GG, 2002. Freshwater blooms, p. 149-194. In: B. A. Whitton and M. Potts (eds.), The ecology of Cyanobacteria. Their diveristy in time and space. Kluwer.

Pavlova V, 2007. Hygiene and analytical aspects of microcystins occurrence in surface water. [Ph.D. Thesis in Bulgarian], National Center of Public Health Protection, Sofia.

Pavlova V, Babica P, Todorova D, Bratanova Z, Maršalek B, 2006. Contamination of some reservoirs and lakes in Republic of Bulgaria by microcystins. Acta Hydrochim. Hydrobiol. 34:437-441.

Pavlova V, Stoyneva M, Bratanova Z, 2013a. Cyanoprokaryotes (Cyanobacteria) and cyanotoxins in some Bulgarian reservoirs. J. Balkan Ecol. 16:257-260.

Pavlova V, Stoyneva M, Bratanova Z, Karadjova I, 2013 b. [Cyanoprokaryotes (Cyanobacteria) and cyanotoxins - health aspects and safety requirements for air transportation, p. 96100].[Article in Bulgarian with English Abstract]. In: Proceedings Scientific Conference "Actual problems of safety", 16-18.10.2013, Publ. Complex of the NVU "Vasil Levski.

Pavlova V, Stoyneva M, Georgieva V, Donchev D, Spoof L, Meriluoto J, Bratanova Z, Karadjova I, 2014. New records of microcystins in some Bulgarian water bodies of health and conservational importance. J. Water Res. Protect. 6: 446-453.

Pavlova V, Stoyneva M, Babica P, Kohoutek J, Bratanova Z, 2007. Microcystins contamination and cyanoprokaryote blooms in some coastal Bulgarian wetlands, p. 221-226. In: Conf. Preprint Book BULAQUA 2007, Sofia.

Pavlova V, Stoyneva-Gärtner M, Uzunov B, Bratanova Z, Lazarova A, Karadjova I, 2015. Microcystins -LR, -YR and
-RR in six Bulgarian water bodies of health and conservational importance (2012-2014). J. Water Res. Protect. 7:1375-1386.

Peev D, Petrova A, Anchev M, Temnsikova D, Denchev CM, Ganeva A, Gussev C, Vladimirov V (eds.), 2013. Red data book of the Republic of Bulgaria. Vol. 1. Plants and Fungi. Institute of Biodiversity and Ecosystem Research of Bulgarian Academy of Sciences and Ministry of Environment and Waters of Bulgaria \& MOEW: 525 pp.

Pettersson LH, Pozdnyakov D, 2013. Monitoring of harmful algal blooms. Springer, Dordrecht: 307 pp.

Reynolds CS, 1987. Cyanobacterial water blooms. Adv. Bot. Res. 13:67-143.

Reynolds CS, 1996. Plant life of the pelagic. Verh Internat Verein Theor Angew Limnol. 26:97-113.

Reynolds CS, 2006. Ecology of phytoplankton. Cambridge University Press, Cambridge: $535 \mathrm{pp}$.

Rott E, 1981. Some results from phytoplankton counting intercalibration. Schweiz. Z. Hydrol. 43:34-62.

Schopf JW, 2012. The fossil record of Cyanobacteria, p. 15-38. In: In: B.A. Whitton (ed.), The ecology of Cyanobacteria II. Their diversity in space and time. Springer.

Šejnohová L, Marsalek B, 2012. Microcystis, p. 195-228. In: In: B.A. Whitton (ed.), The ecology of Cyanobacteria II. Their diversity in space and time. Springer.

Sommer U, Padisák J, 1993. Appendix 1. Identification of equilibrium. In: U. Sommer, J. Padisák, C.S. Reynolds and P. Juhász-Nagy (eds.), Hutchinson's heritage: the diversity-disturbance relationship in phytoplankton. Hydrobiologia 249:5-6.

Stal LJ, 2012. Cyanobacterial mats and stromatolites, p. 65-126. In: B.A. Whitton (ed.), The ecology of Cyanobacteria II. Their diversity in space and time. Springer.

State Order N 4/14.09.2012, 2013. for characterization of the surface waters of the Minister of Environment and Waters. State Gazette 22.

Stockner JG, Callieri C, Cronberg G, 2002. Picoplankton and other non-bloom forming Cyanobacteria in lakes, p. 195231. In: B.A. Whitton (ed.), The ecology of Cyanobacteria II. Their diversity in space and time. Springer.

Stoyanov PS, 2014. [Variability, taxonomy and ecology of some filamentous blue-green algae (Cyanoprokaryota)].[PhD Thesis in Bulgarian], Plovdiv University "Paysiy Hilendarski", Plovdiv.

Stoyanov P, Belkinova D, Mladenov R, Teneva I, 2012. [Analysis of the water in the reservoirs Krushovitsa, Enitsa and Valchovets (Northern Bulgaria) for presence of cyanotoxins, $p$. 237-249].[Article in Bulgarian with English Abstract]. In: PU "P. Hilendarski", Jubilee Proceedings "Biological sciences for a better future".

Stoyanov P, Teneva I, Mladenov R, Belkinova D, 2013. Diversity and ecology of the phytoplankton of filamentous bluegreen algae (Cyanoprokaryota, Nostocales) in Bulgarian standing waters. Ecologia Balkanica 5:1-6.

Stoyanov P, Teneva I, Mladenov R, Belkinova D, 2016. Filamentous cyanoprokaryotes (Cyanoprokaryota/ Cyanobacteria) in standing waters of Bulgaria: diversity and ecology. J. BioSci Biotechnol. 5:19-28.

Stoyneva M, 1998a. Algae, p. 10-37. In: T.M. Michev, B.B. Georgiev, A.V. Petrova and M. P. Stoyneva (eds.), Biodiver- 
sity of the Srebarna Biosphere Reserve. Checklist and bibliography. Co-publ. Context \& Pensoft.

Stoyneva MP, 1998b. Development of the phytoplankton of the shallow Srebarna Lake (North-Eastern Bulgaria) across the trophic gradient. Hydrobiologia 369/370:259-367.

Stoyneva MP, 2003. Steady-state phytoplankton assemblages in shallow Bulgarian wetlands. Hydrobiologia 502:169-176.

Stoyneva M, 2010. [Phytoplankton of the wetland Pomorie Lake, p. 48-60].[Article in Bulgarian with English Abstract]. In: R. Radev, G. Hiebaum, T. Michev and L. Profirov (comp.), Collection of Reports for the Integrated Management Plan for the Protexted area Pomorie Lake BG0000152 and Protected area Pomorie BG0000620, Edition of "Zeleni Balkani" in the framework of the project "Pomorie lake conservation, restoration and sustainable development" GEF 054774.

Stoyneva MP, 2014. [Contribution to the studies of the biodiversity of hydro- and aerobiontic prokaryotic and eukaryotic algae in Bulgaria].[Dr.Sc. Thesis in Bulgarian], Sofia University "St Kliment Ohridski".

Stoyneva MP, 2015. Allochtonous planctonic algae recorded in Bulgaria during the last 25 years and their possible dispersal agents. Hydrobiologia 764:53-64.

Stoyneva M, Descy JP, Vyverman W, 2007. Green algae in Lake Tanganyika: is morphological variation a response to seasonal changes? Hydrobiologia 578:7-16.

Stoyneva-Gärtner M, Uzunov B, Pavlova V, 2016. [Algae in Bulgaria as risk factors for human and ecosystem health, $p$. 15-25].[Article in Bulgarian with English Abstract]. In: Proceedings Scientific Conference "Actual problems of safety" 2016, Publ. Complex of the NVU "Vasil Levski".

Stoyneva MP, Traykov IT, Tosheva AG, Uzunov BA, Zidarova RP, Descy JP, 2015. Comparison of ecological state/potential assessment of 19 Bulgarian water bodies based on macrophytes and phytoplankton (2011-2012). Biotechnol. Biotec. Eq. 29:33-38.

Teneva I, Basheva D, Belkinova D, Dimitrova-Dyulgerova I, Mladenov R, Dzhambazov B, 2011. [Study of the qualitative and quantitative composition of the blue-green algae (Cyanoprokaryota), presence of cyanotoxins and heavy metals in Studen kladenets reservoir].[Article in Bulgarian with English Abstract]. Plantarum (Plovdiv) 41:89-124.

Teneva I, Belkinova D, Dimitrova-Dyulgerova I, Mladenov R, 2009. Phytoplankton assemblages and monitoring of cyanotoxins in Trakiets Reservoir, p. 244-249. In: Scientific Researches of the Union of Scientists in Bulgaria - Plovdiv, series B. Natural Sciences and the Humanities, 12, Technics, Technologies, Natural Sciences and Humanities Session, 56 November 2009.

Teneva I, Belkinova D, Dimitrova-Dyulgerova I, Vlaknova M, Mladenov R, 2010a. Composition and toxic potential of Cyanoprokaryota in Vacha Dam (Bulgaria). Biotechnol. Biotec. Eq. 24:26-32.

Teneva I, Mladenov R, Belkinova D, Dimitrova-Dyulgerova I, Dzhambazov B, 2010b. Phytoplankon community of the drinking after supply reservoir Borovitsa (South Bulgaria) with an emphasis on cyanotoxins and water quality. Centr. Eur. J. Biol. 5:231-239.

Teneva I, Gecheva G, Chesmedjiev S, Stoyanov P, Mladenov R, Belkinova D, 2014. Ecological status assessment of Skalenski Lakes (Bulgaria). Biotechnol. Biotec. Eq. 28:82-95.

Thioulouse J, Chessel D, Dole S, Olivier JM, 1997. ADE-4: a multivariate analysis and graphical display software. Stat. Comp. 7:75-83.

Traykov I, 2005. [Factors influencing the trophic state of the reservoir Kardzhali].[PhD Thesis in Bulgarian], Sofia University "St Kliment Ohridski".

Tsanev AS, Belkinova D, 2008. [Research on the phytoplankton of Ivaylovgrad Reservoir (Eastern Rhodopes Mts., Bulgaria), p. 485-493].[Artcle in Bulgarian with English Abstract]. In: I.G. Velcheva and A.G. Tsekov (eds.), Proceed. "Jubilee scientific ecological conference", Plovdiv.

Vassilev V, Vassilev R, Iankov P, Kamburova N, Uzunov Y, Pechlivanov L, Georgiev B. Popgeorgiev G, Assyov B, Avramov S, Tsenova R, Kornilev Y, 2013. National Action Plan for conservation of wetlands of high significance of Bulgaria 2013-2022. Publication of Bulgaria Biodiversity Foundation, Sofia: 104 pp.

Walker HC, 2015. Harmful algal blooms in drinking water: Removal of cyanobacterial cells and toxins. CRC Press, Boca Raton: $145 \mathrm{pp}$.

Whitton BA, Potts M, 2012. Introduction to the Cyanobacteria, p. 1-14. In: B.A. Whitton (ed.), The ecology of Cyanobacteria II. Their diversity in space and time. Springer.

Whitton BA (ed.), 2012. Ecology of Cyanobacteria II. Their diversity in space and time, Springer, Dordrecht: $760 \mathrm{pp}$.

WHO, 1998. Guidelines for drinking-water quality, health criteria and other supporting information. 2nd ed. Addendum to Vol. 2. World Health Organization, Geneva: 253 pp.

WHO, 2003. Guidelines for safe recreational water enviroments. Algae and cyanobacteria in freshwater. World Health Organization, Geneva: $151 \mathrm{pp}$. 